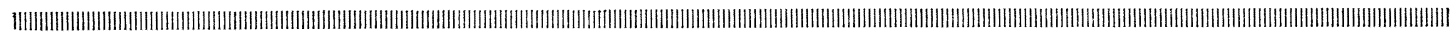

\title{
講座「テレビ・ラジオ技術者のためのマイクロ コンピュータ」の開講にあたって
}

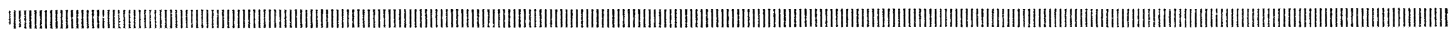

コンピュータは複雑な数值計算をする必要から生れた機器であるが，現在では高度な制御，判断， 姏理などを人間に代って，正確かつ迅速に実行するという機能を果たすようになり，人間の社会活動 をむ制御するような重要な役割を担うようになってきた。一方，LSI 技術の進歩は超小形のコンピュ 一タすなわちマイクロコンピュータを出現させ，高度で複雑な機械と思われていたコンピュータが一 気にわれわれの身近な存在となってきた．今後このマイクロコンピュータは，スタジオ技術や放送技 術にとどまらず，社会活動のすみずみまで入りとんでくるようになるすの上思机れる.

テレビジョン学会では，乙のような情勢をふまえて，てれまでコンピュータになじみのなかった力 々でむマイクロコンピュータを理解し，取扱いができるようにすることを目㭢に，マイクロコンピュ 一夕講座を開設することにした。開講にあたって，約 200 名の方々にアンケート調查在お願いした結 果 $100 \%$ に近い御回答をいただくという多大の御協力を得た．そしてこの調查を参考として，

（1）できる限り平易に記述し，系統的に解説する.

（2） 経験者, 未経験者の過半数の方々の要望により,マイクロプロセッサ 8080 を中に解説する.

（3）実例をあげて，初心者にあ応用ができるように配虑する.

(4) 用語集をつける.

こととしたななお経験者の方々の中にはZ-80，M-6800を説明用に使いたいしいう希望者が多かった が，本請座ではやはり初心者用として 8080 を基本とした。な拈経験者の方々のためには，講座とは 別に up to date な問題としてそれらを取上げ本誌上に解説として揭載することとしたい. また本講 座は統一的な記述をしていただくため各項目を小人数で分担執筆していただくようにお願いした，執 筆者の次は非常に御苦労をおかけするととになるが, 編集委員会としては心から感謝する次第で ある、またアンケート調査に御協力いただいた方には憬く御礼申し上げるとともに，適当な時期に調 査結果を公表させていただきたいと思っている.

テレビジョン学会の会員諸氏におかれては, 本講座についての御意見や御希望を是非編集委員会あ てお寄せいただくようお願いしたい。なお本講座に使用する用語は，学会の用語集に準拠するが，マ イクロコンピュータのようにこれから新しくまた発展する分野は, それに伴なう新語や慣用語が多数 使用される. 執筆者, 読者の相互理解を容易にするためにあ, 本講座ではこ机ら慣用語を使用するこ とを扔許しいただきたい。なお講座における用語の統一をとるためにあマイクロプロセッサー，トラ ンジスターなどあマイクロプロセッサ, トランジスタなどのように, 語尾をのばさないことにしたと とを付記する。

(編集委員会)

\section{〔講座〕テレビ・ラジオ技術者のためのマイクロコンピュータ（全 12 回）}

\author{
(表 題) \\ (筆 者)
}

(掲載予定)

I. 序

1. マイクロコンピュータの出現と放送へのインパクト…和久井孝太郎 $(\mathrm{NHK})$ ・伊藤 鋅 (TBS)

II. 基礎編

2. マイクロコンピュータのハードウェア（I）（II）…….........................池野信一（電電公社）８・9 月号

3. マイクロコンピュータのソフトウェアとインタフェース技術の基礎（I）（II）

III. 応用編 ‥池野信一（電電公社） $11 \cdot 12$ 月号

4. マイクロコンピュータへのデータ入力制御 (I) (II)

5. マイクロコンピュータのソフトウェアの実際（I）（II）

村上敬之助・大関健二・榎並和雅 (NHK) 53 年 $1 \cdot 2$ 月号

.........................................................村上敬之助・大阅健二・榎前和雅 $(\mathrm{NHK})$

$3 \cdot 5$ 月号

マイクロコンピュータのデータ出力制御

松田信義 (日 電)

6 月号

7. コンピュータプロジェクト (I）（II ）…………村上敬之助・六関健二・榎並和雅 (NHK)

$8 \cdot 9$ 月号

（注） 52 年10月，53年 4 月，7 月は特集号となりますので，本講座は休載いたします。なお，表題招よび筆者は変 更されることがありますのでで了承ください。 
講 座 テレビ術者のたジすマイクロコンピュータ （第1回）

I. 序

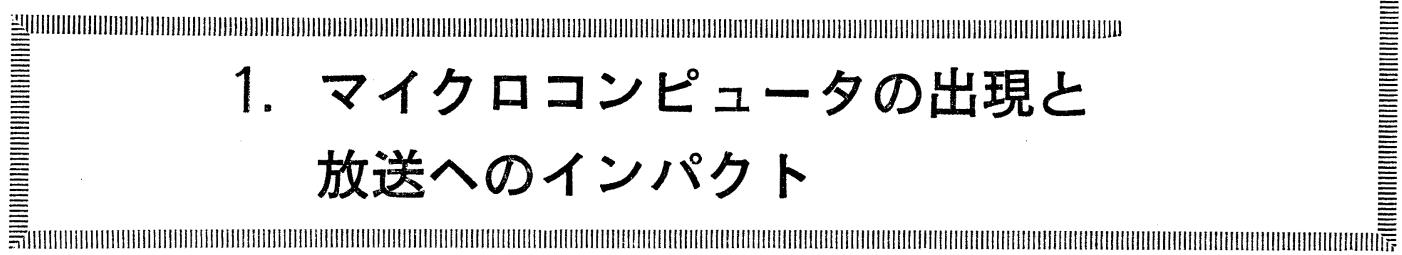

$\begin{array}{rrr}\text { NHK 総合技術研究所 } & \text { 和 久 井 } & \text { 孝太郎 } \\ \text { 株式会社 東京放送 } & \text { 伊 藤 } & \text { 豊 }\end{array}$

\section{1. まえがき}

真空管からトランジスタ, IC へ, 今日の放送の発展 がトランジスタ技術の進歩敒負うとてろが大であるてと は疑う余地がない，この上うな放送を支えている電子技 術はトランジスタ，IC からさらにマイクロエレクトロ ニクスへと急速な展開を見せようとしている，マイクロ エレクトロニクスとは半導体の超精密, 微細加工技術を 主軸とした新しい電子技術の総妳である。

なんだ LSI のことかと思われる人も多いかす知れな い、たしかに LSI はマイクロエレクトロニクスの大き な部分である. しかし，その効果は従来のトランジスタ， IC の単なる延長であると考えるのは正しくない.

技術の進歩には連続的な面之不連続な面がある。一般 的にいって技術とは，今日の不充分さを解決するために 検討対象の高性能化や操作性・信頼性向上, 経済性向上 などを目指していろいろな努力を積重ねて行くものであ る

われわ秃がトランジスタ，ICからマイクロエレクト ロニクスへの進展とその効果を論ずる場合，てのような 技術の連続的な進步について考えることあ重要である が，それが本質的に持っている不連続性，すなわちどん な飛躍やインパクトがあるのかをはっきり見定めるとと がさらに重要である。乙のととを図 1 亿模型的汇示し た.

それではマイクロエレクトロニクスによってむたらさ れる飛躍とは何かというととになるが，現時点ですでに

"Microcomputer Techniques for TV and Radio Engineers; 1 Developmental Progress of Microcomputer and its influence to Broadcust" by Kotaro Wakui (NHK Technical Research Laboratories, Tokyo) and Yutaka Itoh (Tokyo Broadcasting System Inc., Tokyo)
はっきりしている兆候は次の 3 つである.

（1）インテリジェンス機能の普遍化

マイクロコンピュータと半導体メモリはマイクロエレ クトロニクスの現時点に扔ける最大の産物である. 数年 前までは手の平汇乗り，数万円以下で買うことができる ようなコンピュータは夢であった。 それが今日では現実 のあのとなり技術は急速浪拡がりつつある.

ことでいうインテリジェンス機能とは複雑な判断をと あなう自動制御機能のととであり，あらかじめ適切な手 順をメモリに記憶させて抢けばマイクロコンピュータを 活用して大きなスペースを必要とせずに，しかむ経済的 にインテリジェントな機能を持ったシステムを構成する ことができる，そして，今後放送の分野，工業・落業分 野をはじめ一般民需の分野までを含め，あら肿る分野 普及するととが予想される。

(2) ディジタル技術の普遍化

本誌特集号「ディジタルテレビジョン」(1976 年 10月) を捄読みになって画像や音声のディジタル処理と伝送, ヘリカル VTR を放送の分野に登場させたディジタルタ イムベースコレクタ, 同期結合や方式変換の問題を解沠 したフレームシンクロナイザやディジタル方式変換装置 の実用化など，放送分野におけるディジタル技術とは何

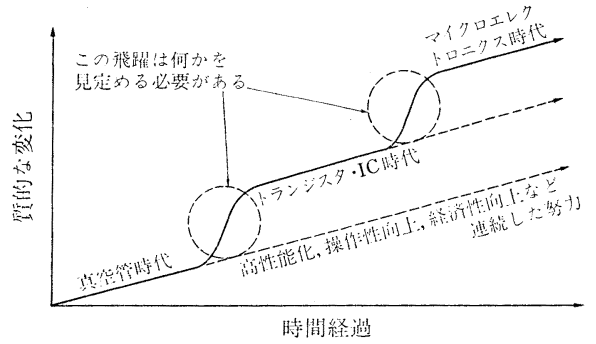

図 1 技術進歩の連続性と不連綕性 
かというととが捄わかりいただけたむのと思う。トラン ジスタ，ICによってディジタル技術は理論から現実の あのとなったが，マイクロエレクトロニクスの進歩はデ イジタル技術のいっそうの発展を約束することになるだ ろう.

将来のディジタル信号処理では, 高速なマイクロコン ピュータ要素が多用されるととが予想される.

(3) 新しい機能デバイスの出現

前述したマイクロコンピュータ, 半導体メモリも新し い機能デバイスであるが，マイクロエレクトロニクスは このようなディジタル的なデバイスだけでなく固体撮像 デバイスや PLL (位相同期ループ) など多くのアナロ グ的な新しい機能デバイスの開発を可能としており, マ イクロコンピュータの出現とあどあ回路設計, システム 設計の考えかたを変えつつある.

放送にとって技術は手段であり道具である. 道具は活 用しててそ意味がある. 本講座では 10 回連続で放送や 関連分野の技術者のためにマイクロコンピュータの持つ 技術的な意味, マイクロコンピュータのハードウェア, ソフトゥェアの基礎, 放送分野における応用など, でき るだけ具体的にわかり易く解説する予定である.

\section{2. 半導体工業の体質とマイクロコンピュー 夕の出現 ${ }^{11}$}

マイクロコンピュータの出現と発展は, 半導体工業の 持っている体質的なものが重要な役割を果しているとい っても過言ではない. 1960 年代のはじめ半導体技術に望 まれたのは，個別部品で組立てられたおびただしい種類 の回路をそのまま IC 化するととであった.

しかし，IC の製造技術は大量生産したときにメリッ トが得られるもので, 本質的には多品種少量生産には不 向きであるといったとと, 設計可能な電気パラメータが ある範囲に限定されるととや精度からくる制約などから てれらの要望を満足することができなかった.

半導体工業のこのような行きづまりはメーカによる 洒格の引き下げとアナログ回路におけるオペアンプ，デ ィジタル回路に拈ける TTL (transister transistor logic) などの IC 標準化の努力によって一応の打開をみせた が，1960 年代を通して IC 化の対象となる回路はますま す複雑化する傾向を示し, 複雑化に伴なう沉用性の欠如 とコスト増大が半導体工業のボトルネックとなることが いっそうはっきりしてきた．多品種少量生産に適した生 産技術の研究む多数行われたが, あまり成功しなかった.

この間に半導体技術は複雑な回路を大量生産できるマ イクロエレクトロニクス技術を育成しつつあったが，䒠 際に適用すべき対象がなかなか見つからなかった，格好
なテーマを最初に提供したのは, 半導体メモリである. 半導体メモリはチップの集積度が増すほどビット当りの 単価は低下し, 大量に使用される可能性があった.

むうひとつは電卓である．乙れはで存知のように大量 生産によって複雑な機能を比較的安い価格で実現するて とができ急速に普及した，しかし，他にはてのようなテ 一マはなかなか見つからなかった，そこへ第 3 のテーマ として登場したのがマイクロコンピュータである.

マイクロコンピュータは非常に複雑な回路であるが, 沉用性を失なわないとてろが半導体工業と結び付きメリ ットが得られる最大の理由がある. そして，マイクロコ ンピュータの出現はプログラマブルな処理ユニットが低 価格で，どとであ誰であ使えるようになったてとを意味 し，半導体技術にとってもコンピュータ技術にとっても 革新的なできでとであった．マイクロエレクトロニクス とマイクロコンピュータは打互い仁刺激しあって今後い っそうの進展を見せることになろう。

筆者の一人はカラーカメラのレジストレーションやカ ラーバランスを自動的汇調整する目的で, 最近 12 ビット つハイブリッドLSI 化されたワンパッケージ・マイク ロコンピュータを開発したが，乙れはそのままカラーカ メラ以外の放送機器の制御に適用できるととはむちろん であるが，少しもったいないということを我慢すれば， プログラムを変更するだけで同期信号発生器にす時計に あなる.このようなととは, 従来の電子回路にはなかっ たことで，電子回路とは何かという新たな疑問をなげか ける出来でとであある.

\section{3. マイクロコンピュータとマイクロプロセ ッサ}

マイクロコンピュータ (microcomputer) 以外にマイ クロプロセッサ (microprocesser) という言葉が今後とき どきでてくると思う、筆者らあそうであるが，半導体技 術やマイクロコンピュータの勉強をしようとすると, 聞 きなれない新しい言葉が次から次へとでてくるので閉口 してしまう. 専門用語は, 使いなれた人々にとっては効 率的で便利なむのであるが，専門外の人々を閉め出すと とにもなりかねない，本講座では重要な用語は最後にま とめて説明を加えてある.

図 2 はディジタルコンピュータシステムのごく一般的 な構成図である，マイクロコンピュータとはこのような ディジタルコンピュータシステムをワンチップまたは複 数チップの LSI デバイスを中心に構成したあのをさす. 一方，マイクロプロセッサとは，乙の上うなコンピュ ータシステムから入出力装置やメモリ装置などを除き, コンピュータの論理的処理機能の中心である CPU (cen- 


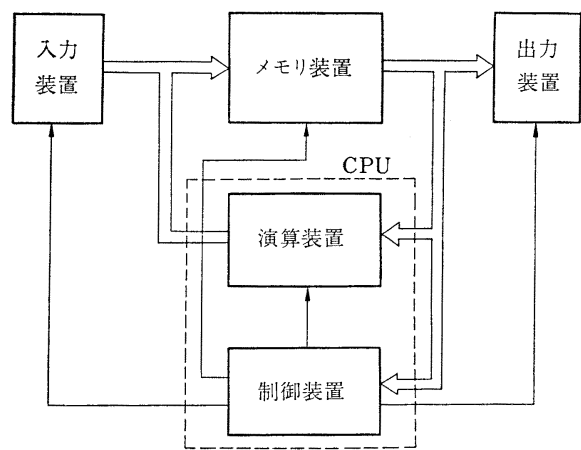

$\Longrightarrow$ 一テータ·命令の流れ

$\longrightarrow$ 制御情報の流れ

図 2 ディジタルコンピュータシステムの基本的な構成

tral processing unit, 中央処理装置) を主体とした部分 のことである(後出の図 3 参照)。すなわち，マイクロプ ロセッサはマイクロコンピュータの主要部分であるが, 制御手順（プログラム）や制御数值（データ）などを記 憶するためのメモリは含まれていないと覚えていただく のが簡単である。 マイクロプロセッサは場合によっては ワンチップ CPU とか，マルチチップ CPU といった表 現が使われることがある.

最初のマイクロコンピュータは米国 Intel 社の MCS4 (1971 年) である，乙れはより高性能で経済的な電卓
を開発する目的で, 日本のメーカの依頼によって開発し たものであるといわれている，そして，てのシステムに 用いられている MOS-LSI ワンチップマイクロプロセ ッサが 4004 である.

これは 4 ビットのマイクロコンピュータで論理演算命 令*や割込み（インターラプト）機能*がなく、ミニコン 的な使用目的には充分ではなかったが，1972 年に同じ Intel 社から 8 ビットのマイクロコンピュータ MCS-8 (マイクロプロセッサ 8008) が発表されて，本格的なマ イクロコンピュータ時代を迎えることになった。

その後，4004 や 8008 は，電卓外汇むいろいろな目的 亿使用された結果，4004などでもかなり広い応用分野が あるが 8008 であ充分でなく，むう少しマイクロプロセ ッサの機能が向上すれば，さらに広い応用分野があると とむはっきりしてきた，そこで 4004，8008 に対する改 良要求をまとめ, 1973 年末にマイクロプロセッサ 8080 が発表された。

8080 の成功はメモリに続いてマイクロコンピュータ が半導体工業にとって非常に大きなテーマであることを はっきりさせた. そして, Fairchild, Motorola, National Semicon., Rockwell, Signetics, Texas Instruments などの外国半導体メ一力，富士通，日立，三菱，日電， 沖電, 東芝などの国内半導体メーカ各社がマイクロプロ セッサやマイクロコンピュータを競って開発するように

\section{*次回以下でくわしく俤明される.}

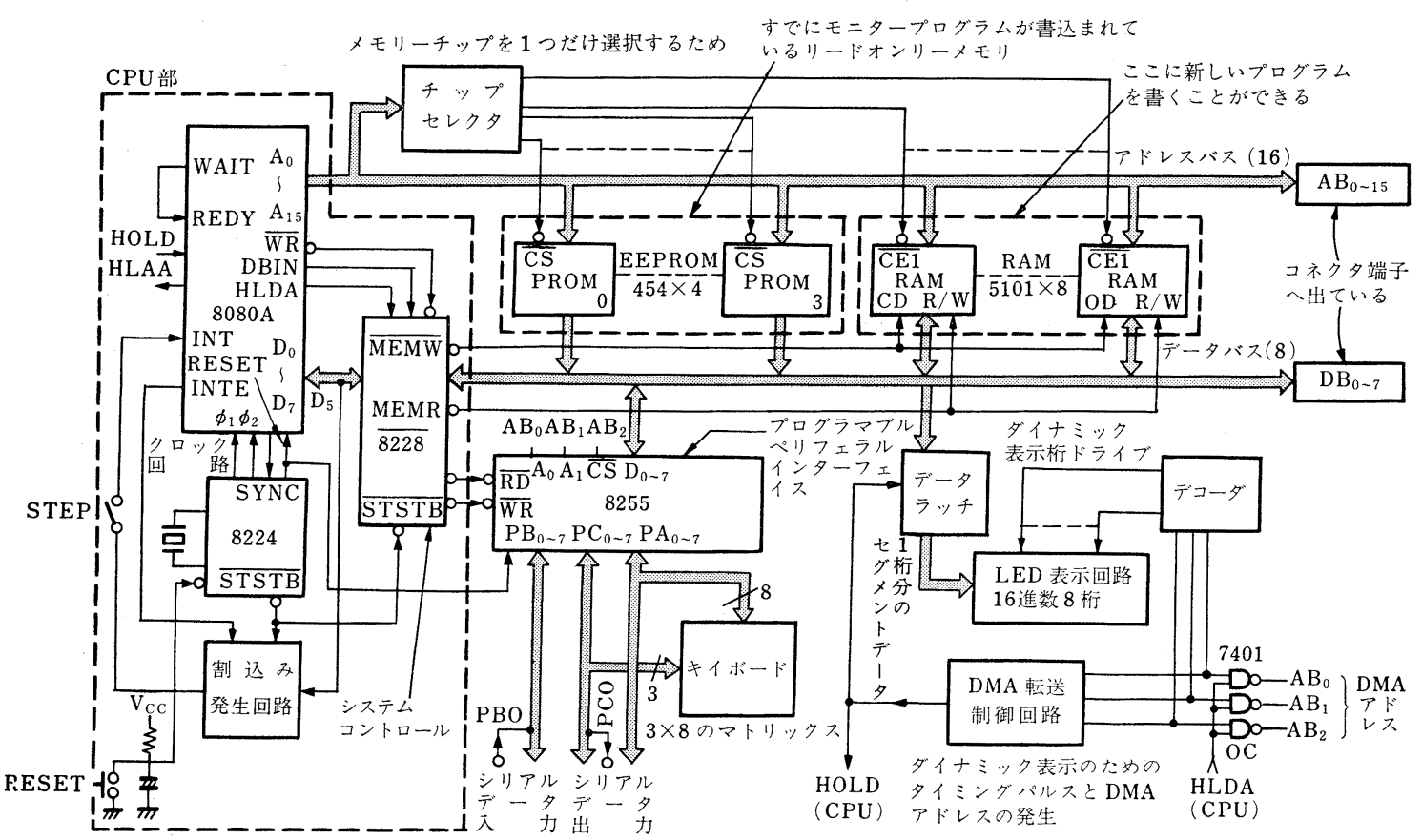

図 3 TK-80 のシステム構成

（今回はこの図面の細部について検討される必要はありません．概要を見てください） 


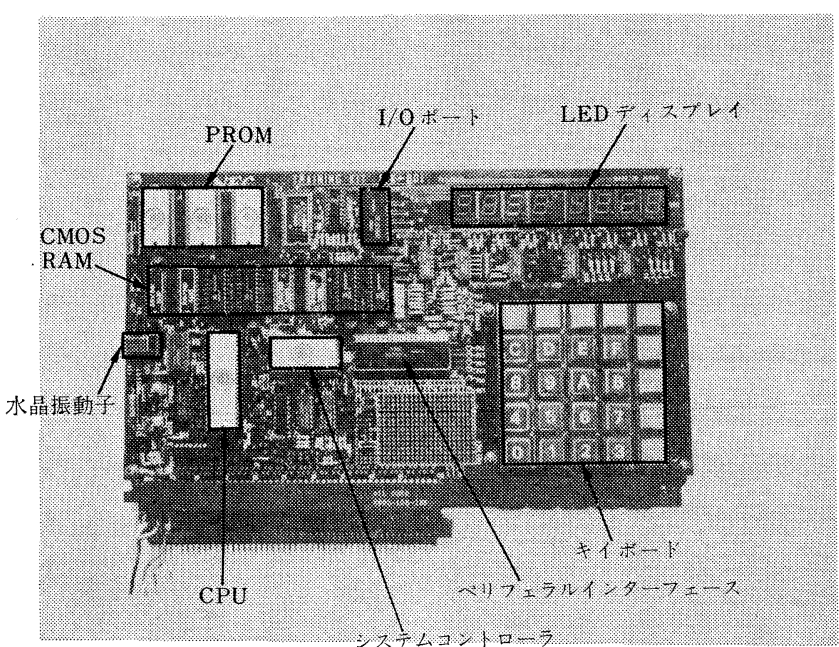

図 4 組立てられた TK-80 マイクロコンピュータ

なった. 最近では比較的高度な機能を持ったワンチップ のマイクロコンピュータが開発されるまでになってい る.

一方，マイクロコンピュータに対する一般的な関心の 高まりあ大きく, 上記の数社が発表したマイクロコンピ ユータキットは, アマチュアのマイコンクラブができる など大いに受けているようで, 放送関係の皆さんにす自 分で手にとっていろいろ実験を試みられた方す多いので はないかと思う。
図了は先に述心゙た Intel 社のマイクロプ ロセッサ 8080 と互換性を持つ日電製のマ イクロプロセッサ $\mu \mathrm{PD} 8080 \mathrm{~A}$ を用いたマ イクロコンピュータキット TK-802) のシ ステム構成を示すむので，組立てられたマ イクロコンピュータの外観を図 4 に示し た。

これはマイクロコンピュータのトレーニ ングを主目的としたすので，入出力装置 としてキイボードと 8 桁の LED ディスプ レイを備えており，高価な外付け入出力装 置を使用することなしにプログラミングの 練習ができるようになっている．取扱い説 明書をよく読み先端 $1 \mathrm{~mm}$ ほよ゙のハンダご てを用いて，ていねいに組立てれば，容易 に動作するが，さて練兒間題以外にマイク ロコンピュータに自分の目的の仕事をやらせようとすれ ば，インターフェース技術やプログラミング技術，さら にコンピュータ技術全般についてむう少し深く知らなけ ればならないことがわかる。

\section{4. マイクロコンピュータの放送への応用 ${ }^{3)}$}

マイクロコンピュータあるいはマイクロプロセッサ的 なものが，将来の放送によ゙のように応用できるかは現在 までにすべてがはっきりしているわけではなく，今後ま

表 1 マイクロコンピュータの応用

\begin{tabular}{|c|c|c|}
\hline 応用 分野 & シ ス テ ム構 成 & 志 用 例 \\
\hline $\begin{array}{l}\text { 文字・図形の発生と制御 } \\
\text { (ディスプレイ制御) }\end{array}$ & 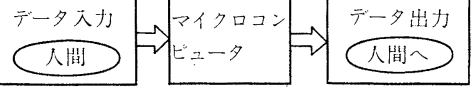 & $\begin{array}{l}\text { ・文字, 図形のディスブレイ } \\
\text { ・特殊効果波形発生 } \\
\text { ・テレレ゙ゲーム }\end{array}$ \\
\hline シーケンス制御 & 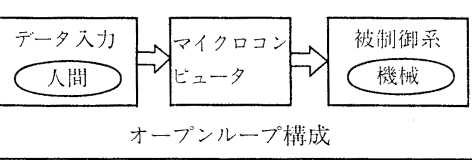 & $\begin{array}{l}\text { ・番組自動送出 } \\
\text { ・音声調整卓 } \\
\text { ・照明コントロール } \\
\text { などの各種プリセット装置 } \\
\text { な゙ }\end{array}$ \\
\hline データーロギング & 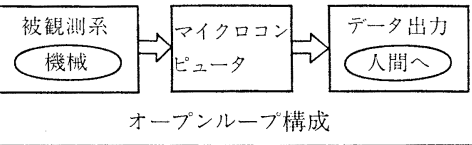 & $\begin{array}{l}\cdot \text { 回線の自動测定 } \\
\text { ・機器の管理データ収集 } \\
\text { ・機器の故障診断 }\end{array}$ \\
\hline $\begin{array}{c}\text { DDC } \\
\text { (プロセス制御) }\end{array}$ & 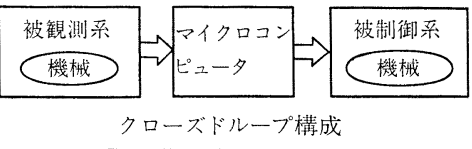 & $\begin{array}{l}\text { •FPUバラボラアンテナの } \\
\text { 自動方向調整 } \\
\text { ・カラーカメラの自動調整 } \\
\text { などの高級な自動制御 }\end{array}$ \\
\hline 画 像 処 理 & 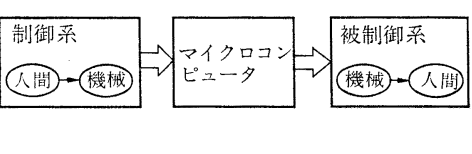 & $\begin{array}{l}\text { ·電子ズーミング, 押出し, } \\
\text { 回転などの特殊効果 } \\
\text { ・将来はスキャニメイト, } \\
\text { ニメーションなどの画像の } \\
\text { 合成制作など }\end{array}$ \\
\hline
\end{tabular}




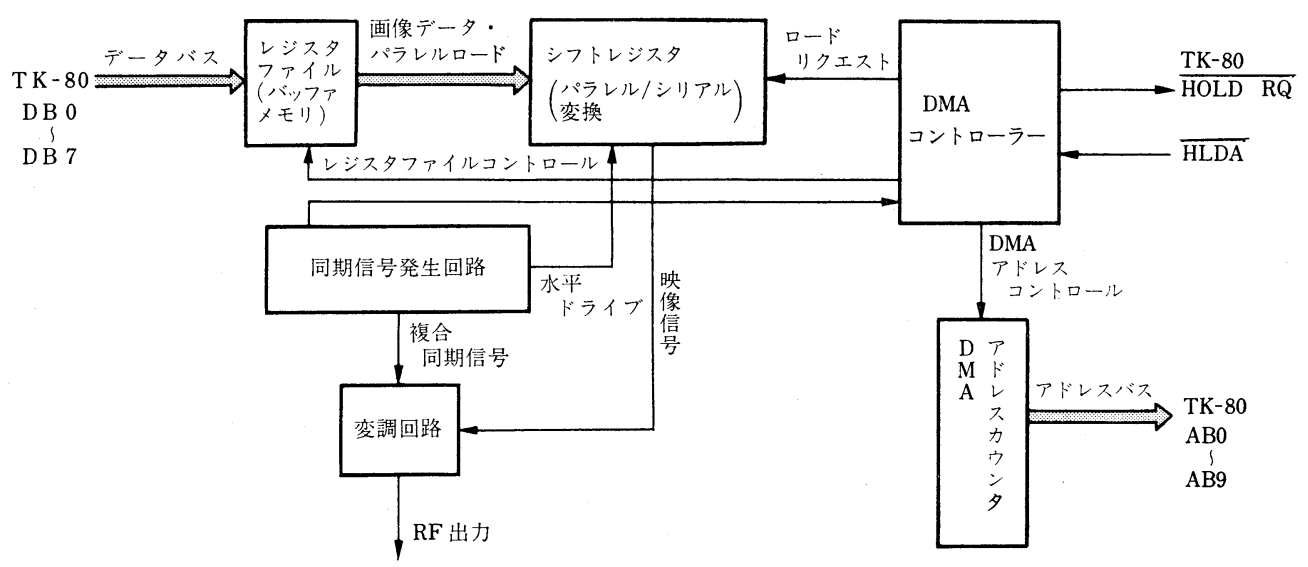

図 5 TK-80 を使用したテレビゲームのインターフェース部（図 3 と合せて見てください）

ったく新しい応用むいろいろ開発されるとみられるが, ここではマイクロコンピュータの応用の基本パターンを 分類し，具体的な 2,3 の応用例について述べる.

表1にマイクロコンピュータの応用をシステム構成上 から分類して示した．このような分類では文字，眓形の 発生と制御（ディスプレイ制御）応用，シーケンス制御 (sequential control) 応用, データロギング (data logging）応用，ダイレクトディジタル制御 (direct digital control, 以下 DDC) 応用, 画像処理 (image processing) 応用の 5 つがある.

これらとは別に, ディジタル信号の掛算, 微分, 積 分, 各種の処理といったような応用などああるが，乙こ ではふれない。

\section{1 文字・図形の発生と制御応用}

キャラクタディスプレイ(テレビ文字パターン発生), ロータリーワイプなどの特殊効果波形発生, グラフィッ クディスプレイ（テレビ図形パターン発生）などがあ り，最近話題のテレビゲームなどもこの分類に入る.

このようなシステムでは表 1 にむ示したように人手に よってデータ入力を行い, マイクロコンピュータはこの 情報を受けあらかじめ定められた手順によって必要な処 理を行い，映像の信号の形で人間へ文字や図形をディス プレイするあのである.

図 5 は先に述べたマイクロコンビュータキットTK80 を使用してテレビゲームを行うための TV インター フェースを示したものである2). インターフェース部は 同期信号発生回路, DMA (direct memory access) コン トローラ, 映像信号変調回路からできている.

テレビゲーム応用ではゲームの内容に応じてあらかじ め制御プログラムをマイクロコンピュータのメモリに記 憶させて怙き, 遊び手が入力する情報を解読して, ゲー ムの進行に必要な画像情報データをマイクロプロセッサ
が発生・編集してデータをいったんメモリに格納し，テ レビ受像機に合った画像データとして転送するあのであ る.

図中, DMA コントローラとあるのはマイクロコンピ ュータのメモリから画像データをテレビ走査レートで読 出すために必要な制御を行うむのである. DMA 機能に ついての本格的な説明は後続の講座で取り扱うむのとし て，乙こではこのシステムに関しての簡単な説明にとど める.

通常, マイクロコンピュータ内のメモリは CPUが 1 ステップごとに制御して，命令やデータの出し入れを行 っている.一方，CPUが編集してあらかじめデータを 格納したメモリからテレビ走査レートで情報を読出すに は，CPUを切り離し同期信号発生回路で発生させたタ イミングパルスで直接メモリを制御する、このように CPUを介さないでメモリを直接呼び出す（アクセス） 方法を DMA と呼んでいる。

\section{2 シーケンス制御応用}

人手によってデータ入力を行い，決められた順序に従 ってコンピュータが次々と制御動作を行うむのをシーケ ンス制御という。放送分野でのコンピュータ制御応用と しては，乙れまでこの種のあのが最む多く開発，実用化 されており番組自動切替送出方式などは代表的な例であ る.

一方, マイクロコンピュータを用いるシーケンス制御 では, マイクロコンピュータの機能から考えて, 多数の 入出力機器を制御するような大規模なシステムへの応用 は不向きで，比較的簡単なプリセット切替えシステム， たとえば音声調整卓や照明コントロールシステムなど， 制御のステップ数が数百以下の規模のシステムに向いて いる，すなわち，従来のリレー万式などによるハードウ エア的なシーケンス制御に対して，フレキシビリティが 
大であり制御内容が比較的容易に変更でき，小形で信頼 性の高いシステム構成ができるのが特長である.

てのようなシステムに抽胡クロコンピュータの 主たる機能は，入力データを解読，編集して制御に必要 なタイミングパルスなどを発生するむのである.

\section{3 データロギング応用}

データロギングといっても耳なれない方む多いのでは ないかと思うが, logging とは本来航海日誌をつけると いう意味であり, データロギング応用は, 観測対象から 必要なデータを自動的に測定し，処理を行って人間に対 して所定のフォーマットでデータを報告するすのであ る.

すなわち，測定の手順やデータ処理，ディスプレイ機 器の制御をマイクロコンピュータによって行う。たとえ ば管理データ報告, 自動監視, 故障彰断, 警報発生シス テムなど放送の分野でむ今後多くの応用が期待される.

特にディジタルシステムでは従来のアナログシステムの ように，オシロスコープで入出力波形を見て簡単に動作 をチェックすることはできないととが多いので，データ ロギングはディジタルシステムの故障診断などで必要不 可欠な技術となるだろう。

図6 は音声特性の自動監視を行うためのデータロギン グシステムの例である ${ }^{4)}$. このシステムは,

（i）放送終了後の短い時間で特性の自動測定

（ii） 毎時, 時報音の測定監視

（iii）放送プログラムの切れ目に音声試験信号を插入 し自動測定

などを行う. 測定結果として周波数特性, 直線性, ひず み率，SN 比などがレポートされる。

てのシステムでは BCD (binary-coded decimal, 2 進 化 10 進数）により出力の周波数とレベルが制御できる プログラマブルオシレータを用いて測定信号を発生させ 被監視系汇印加し，その出力を $\mathbf{A} / \mathbf{D}$ 变換してマイクロ

コンピュータで読取り, 必要な処理を行った後にテレタ イプによりデータを出力する．また，異常值に対する警 報レベルをあらかじめプログラムで設定しておき，異常 があった場合には操作卓に警報を発生するととむにテレ タイプで報告する.

ここでのマイクロコンピュータの主たる役割りは，ア ナログデータの読取りと数值処理である.

\subsection{DDC 応用}

DDC はコンピュータを活用した高級な自動制御方式 である. 前 3 項の応用とは異なり運用時に人間は直接関 与せず，プログラムは制御目的に応じていったん開発さ れると長期にわたって変更されることはない，その意味 においてプログラムは完全にハードウェアの一部と見な すととができる．また，マイクロコンピュータ自身む小 形，組込み性などが重視され，部品として取扱われて行 く傾向にある。

DDC の主な利点は，

（i）複雑な制御応用に対してハードウェアのみによ る制御と比較し，システム構成を簡素化することが できる.

（ii）測定のつど制御系を自己較正することによって ドリフトなどの影響を防止でき，系の安定度を向上 させることができる。

（iii） 直接的に測定できる制御対象の誤差のみではな く，いくつかの検出データから計算処理によって必 要な情報を得るとともできる，すなわち，間接測定 ができ，制御の適用領域を拡げることができる.

（iv）信号平均化など高度なデータ処理ができるので 制御精度の向上をはかることができる。

などがあり，高級なフィードバック制御システムや，目 的によってはフィードフォワード制御システムなども構 成できる。

(1) FPU パラボラアンテナの自動方向調整5)

FPU 受信パラボラアンテナは, サイドビ

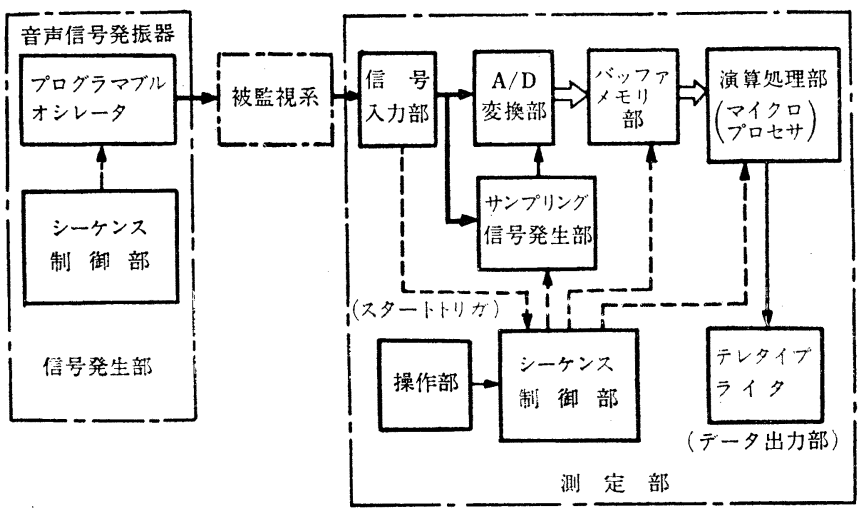

図 6 音声特性自動監視装置の構成 一ムや反射波のために，正確な方向調整を行 うことがむずかしく設定にかなりの熟練を要 する，乙のシステムは従来手動操作で行って いた電界検索，アンテナの方向合せなどの作 業をマイクロコンピュータに行わせるむので ある. 図 7 に示したように 5 基のパラボラア ンテナは無人化された送信所の鉄塔に取付け られており，スタジオ側から電話線を介して 還隔制御される.

これは DDC システムの一種であり，マイ クロコンピュータは受信電界データとアンテ ナ角度データを読取り，プログラムによって 


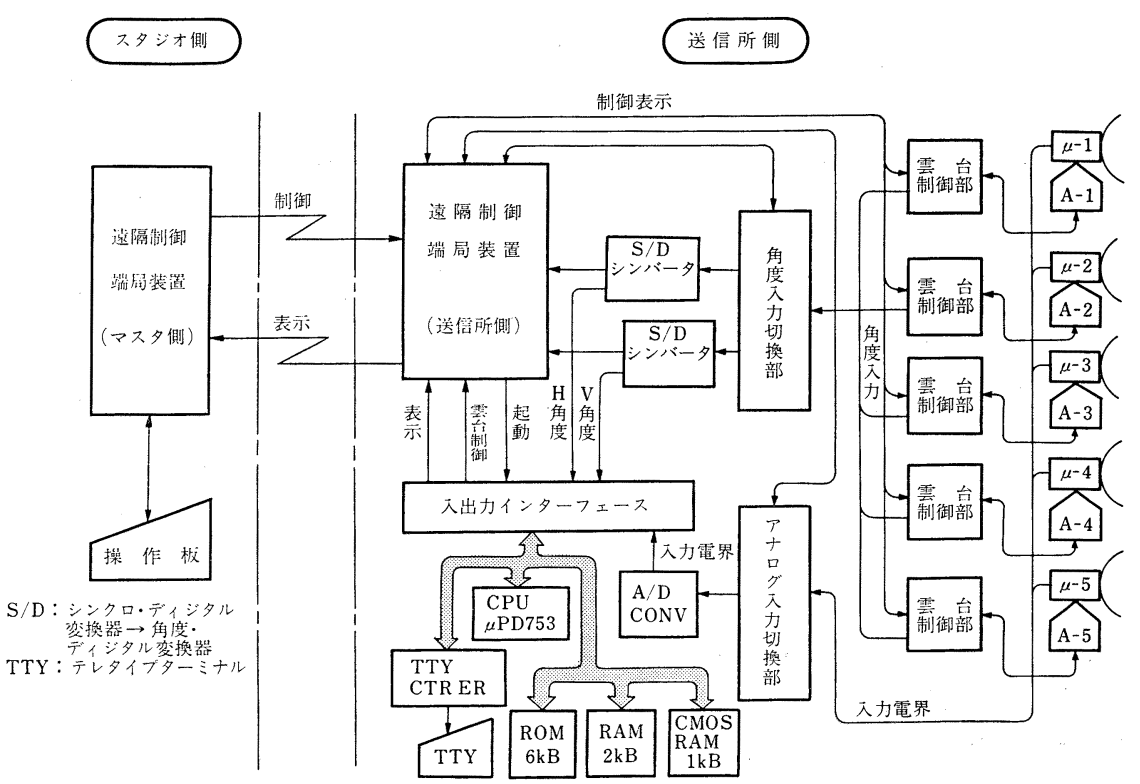

図 7 パラボラアンテナ自動方向調整システム構成

定めら机た処理を行ってフィードバック制御するあので ある. 図 8 亿制御のフローチャートを示した.

(2) 小形カラーカメラの自動調整 ${ }^{3)}$

最近では小形カラーカメラはいろいろな番組制作に利 用され効果を上げているが，使用目的によっては充分な モニタ装置なしで運用しなければならないことがあり， カラーバランスやレジストレーション調整の自動化が望 まれている，図 9 はマイクロコンピュータを利用した自 動調整システムの系統図であり, 典型的な DDC システ ムの一種である.

このようなシステムの設計では図 10 に示したような いろいろな項目について検討し, それぞれについて最適 設計を行い，効率的なシステムを構成しなければならな い. 第 1 亿制御項目に対応する被制御対象の誤差量を高 精度で高速に訫測する検出技術が重要である，第2 亿は 効率的なデー夕処理技術が, また第 3 には計算処理され た出力データをマッチングの良い形で被制御機器に加 え，そのデータを必要な期間保持するなどの操作技術が 重要である.

\section{5 画像処理への応用}

ディジタル画像処理の進歩により, 放送の分野でむ夕 イムベースコレクタ, フレームシンクロナイザ, 方式変 換, 電子ズーミングはむちろんのとと, 輪郭補償やノィ ズ低減装置む実用化されている，乙のように従来のアナ ログ回路では得られなかったもの, あるいは信頼性, 経 済性の点でアナログに置き替るむのまでが続々と開発さ れるものと思わ机る。乙れらの中で複雑な処理を伴うむ

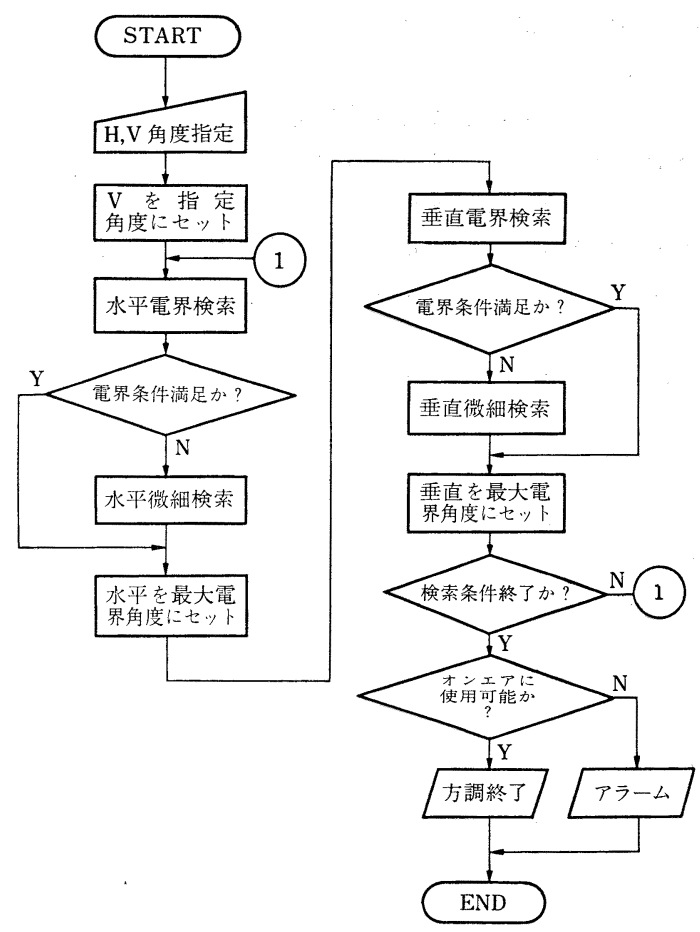

図 8 自動方向調整のフローチャート

のは当然コンピュータを利用することになるであろう.

しかし, リアルタイムでの画像処理では, 現在のコン ピュータの処理速度ではかなりの制約を受けるであろう が, 今後てれらの技術の進歩発展により, スキャニメイ トやアニメーションのような高度なむのにまで発展する 


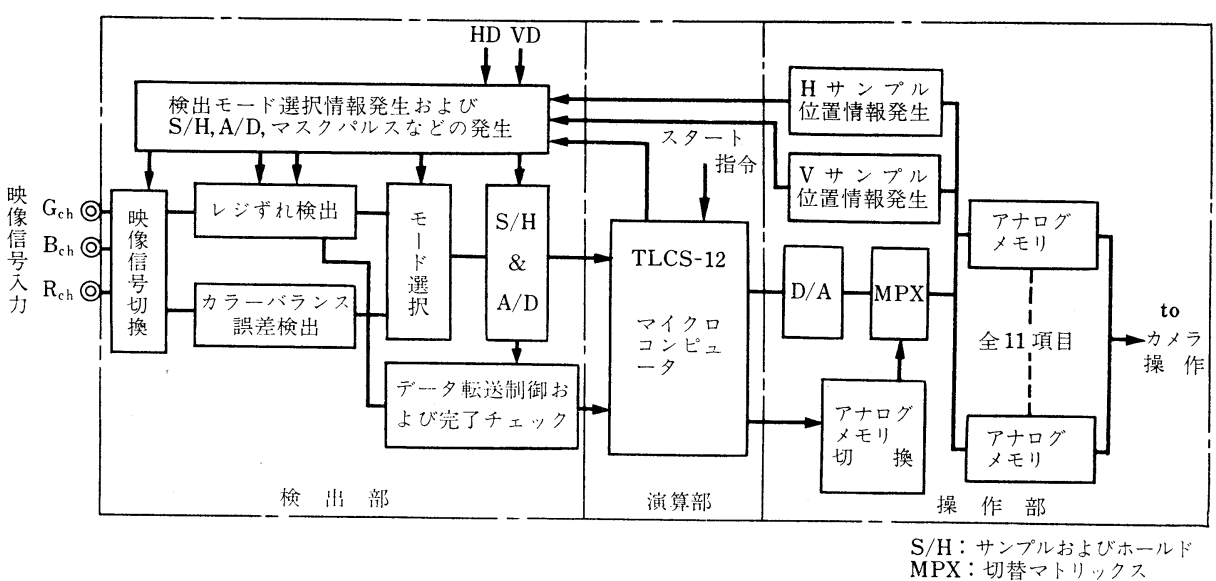

図 9 小形カラーカメラの自動調整システム

であろう.ここではマイクロコンピュータを利用した 電子ズーミング6)7)について述べる.

ディジタルフレームメモリを使用し，画像サイズを 連続的に縮小したり，拡大したりする特殊効果を電子 ズーミングと呼ぶ.たとえば $1 / 4$ に縮小する場合は, 縮小画面の画素数を原画の画素数の $1 / 4$ にすることに よって行われる.

縦方向の $1 / 2$ 縮小は走査線を半分にすれば実現でき るが，単純に間引いたのでは斜めの線や輸郭に幾何ひ ずみを生ずるので，隣り合う上下 2 本の走査線から両 方の情報を含む 1 本の新らしい画素を演算処理によっ て作り（この合成操作をライン内插という），乙れを メモリに書込む.

横方向の $1 / 2$ 縮小についても同様で, 隣り合う画素 より内插演算（ドット内插）によって画素数が半分の 新らしい画素を作り，メモリに書込む：乙の場合, 書 込アドレスのスピードを通常動作の半分にすると， 縦 横の縮小が同時に行われてメモリ上に書込まれる.

読出しは通常のスピードで行うことによって縮小画像 が得られる. 縮小画像のラスタ上任意の位置への移動 は，書込アドレスを制御するととによって行われる。

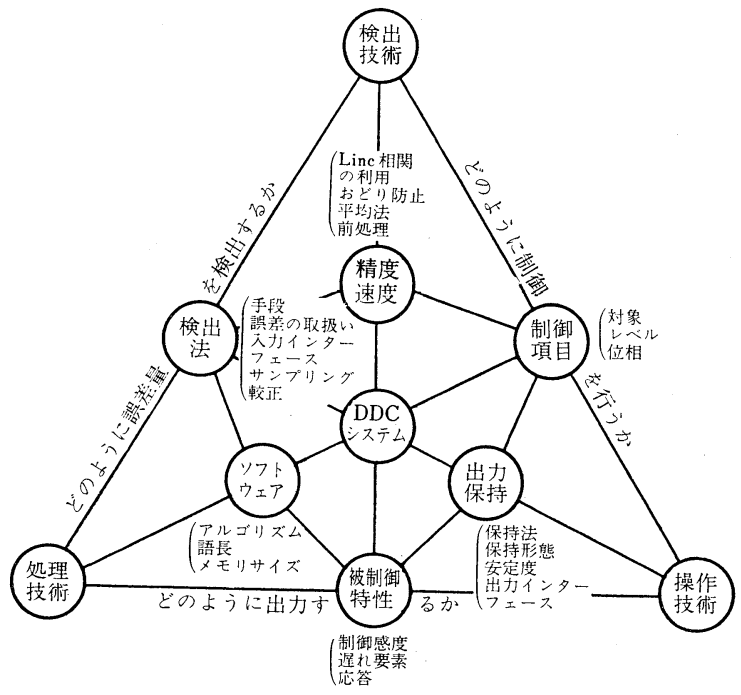

図 10 主要な設計検討項目

図 11 はマイクロコンピュータを利用し，このような 方式による電子ズーミングやその他の特殊効果を行うた めのシステム構成の例 ${ }^{6)}$ を示したものである.

縮小画像の大きさはオペレータがジョイスティックや フェーダ，またはワイプ波形やカメラで撮っ たクロマキー信号などを操作することによっ て決定する。図 12 は入力のキーイング波形 (クロマキー信号やワイプ波形) に連動して 縮小画像在作るとき，マイクロコンピュータ を用いて基礎データを得るときの样子を示し たすのである

方形 A, B , C, D は標準テレビジョン方式 の画像枠(ラスタ)，その中に斜線で示したの がキーイング波形であり，乙れに外接する力 形 $\alpha, \beta, \gamma, \delta$ が求める縮小画像のメモリ上の 


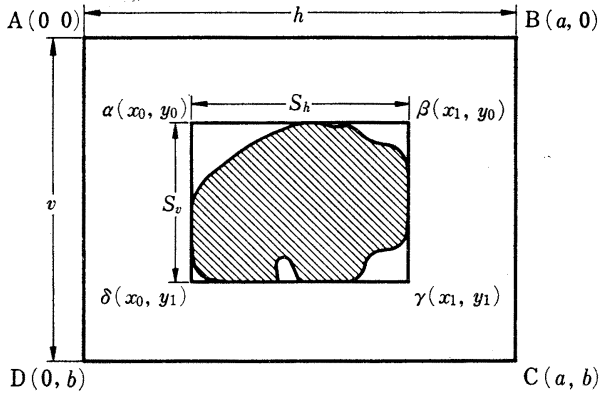

図 12 キーイング波形と外接の方形枠信号

書込み場所となる。

てのデータの発生は次任示す方法によっている.すな わち有効画面上で, 最初にキーイング信号の現われる走 査線のアドレスと, 最後にキーイング信号の現れた走査 線のアドレスを打の扔の求め $y_{0}, y_{1}$ とする. 一方, 水 平のアドレスは水平ブランキングの後縁を起点とし, 各 走査線ごとにサンプリング周波数を用いて計算し， 1 フ イールドの全走查線にアドレスの最小と最大を記録し $x_{0}, x_{1}$ とする. 乙のようにして求められた 4 点 $\alpha\left(x_{0}\right.$, $\left.y_{0}\right), \beta\left(x_{1}, y_{0}\right), \gamma\left(x_{1}, y_{1}\right), \delta\left(x_{0}, y_{1}\right)$ のデータから, $S_{h}$ $(=\overline{\alpha \beta})$ と $S_{v}(=\overline{\alpha \delta})$ を求め, さらに ${ }^{3 / 4} S_{h}$ と $S_{v}$ を比 較して大きい方のデータで縮小率 $\left(S_{h} / h\right.$ または $\left.S_{v} / v\right)$ を 求める.

この縮小率のデータは, ライン内插またはドット内插 の演算回路に送られ, 荷重比を決定する重要なデータと なると同時に，書込アドレスのスピードをむ制御する. また，書込み開始は， $\alpha$ の $x_{0}, y_{0}$ のアドレスデータが そのまま用いられる.

以上の基礎データは每フィールドでとに更新する必要 があるので，プログラムのステップ数などにも考慮する 必要がある.

以上，マイクロコンピュータの応用をシステム分類的 な見地に立って検討したが，マイクロコンピュータをブ ラックボックスと見なし，主としてどんな機能を果して いるかといった動作面から分類すると, マイクロコンピ ユータ応用とは, マイクロコンピュータの次に述べるよ うな機能を活用するむのであるというととあできる.

(i) 判断処理的な機能

(ii) 数值計算処理的な機能

（iii）メモリに記憶されたデータの編集機能

（iv）必要なタイミングパルスを発生したり，パルス 列を発生する機能

（v）データを測定する機能

（vi）外部機器を制御する機能

この中で(vi)はいずれの応用でもほぼ共通に利用され
表 2 マイクロコンピュータの果す機能

\begin{tabular}{|c|c|c|c|c|c|c|}
\hline $\begin{array}{l}\text { システム } \\
\text { 分 } \\
\end{array}$ & $\begin{array}{r}\begin{array}{r}\text { マイコンが } \\
\text { 果してい } \\
\text { る機能 }\end{array} \\
\text { 応用例 }\end{array}$ & データ & 判断 & 計算 & \begin{tabular}{|l}
$x モ り$ \\
データ \\
の編集 \\
\end{tabular} & $\begin{array}{l}\text { パルス } \\
\text { 発 生 }\end{array}$ \\
\hline \multirow{2}{*}{$\begin{array}{l}\text { ディスプ } \\
\text { レイ制御 }\end{array}$} & $\begin{array}{l}\text { 文字, 図形のディ } \\
\text { スプレイ }\end{array}$ & & & $\triangle$ & 0 & 0 \\
\hline & 特殊効果波形発生 & & & 0 & $\triangle$ & 0 \\
\hline \multirow{2}{*}{$\begin{array}{l}\text { シーケン } \\
\text { ス制御 }\end{array}$} & 番組自動送出 & & 0 & & 0 & 0 \\
\hline & 照明プリセット & & & & $\triangle$ & 0 \\
\hline \multirow{2}{*}{$\begin{array}{l}\text { データロ } \\
\text { ギング }\end{array}$} & 特性自動测定 & 0 & O & 0 & & \\
\hline & 故障診断 & 0 & 0 & & & \\
\hline \multirow{2}{*}{ DCC } & \begin{tabular}{|l|} 
アンテナの自動方 \\
向調整
\end{tabular} & 0 & 0 & ○ & & \\
\hline & カメラの自動調整 & 0 & 0 & 0 & & \\
\hline 画像処理 & 電子ズーミング & & 0 & 0 & $\triangle$ & 0 \\
\hline
\end{tabular}

ているので，乙れを除外して，先に述べた各制御応用は どのような機能を利用しているのかを表 2 亿示した.

\section{5. マイクロコンピュータを活用するために 必要な知識}

マイクロコンピュータ応用は, 乙れまでの説明でむお わかりいただけたように，マイクロエレクトロニクス技 術, ディジタル技術, ディジタルコンピュータ技術, 自 動制御技術など，多くの技術の総合されたむのであるか ら，マイクロコンピュータを使いこなし活用するために は, 図13亿示したようないろいろな知識が必要となる. 大別するとハードウェアに関する技術と，ソフトウェ アに関する技術ということになるが，マイクロコンピュ 一タの特色は，すでに述べたように回路機能がプログラ ムによって決定される汎用ディジタル回路システムであ り，ハードウェアとソフトウェアが抔いに助け合って 広沉な目的に適用できるあのであるということを充分認 識するととが大切である.

すなわち，設計者がハードウェアとソフトウェアの両 面について精通して抢り, 適切なハードウェアの選択と 効率的なソフトウェアの開発ができたときに素晴しい効 果が得られるということである. このととは従来の大形 コンピュータ応用の場合と大変様相を異にする点であ る. 従来の大形コンピュータではハードウェアはあらか じめ決められて抢り，一般のユーザの手のとどかないむ のであった，それだけマイクロコンピュータは技術者に とって勉強のしがいのあるテーマであるということあで きる。

マイクロコンピュータを活用しようとする場合，むう ひとつ忘れてはならない基本的な事項は，自分は何に対 してどんな目的で応用しようとしているのかを明確にす ることである. 応用される側の問題点の掌握と分析が充 


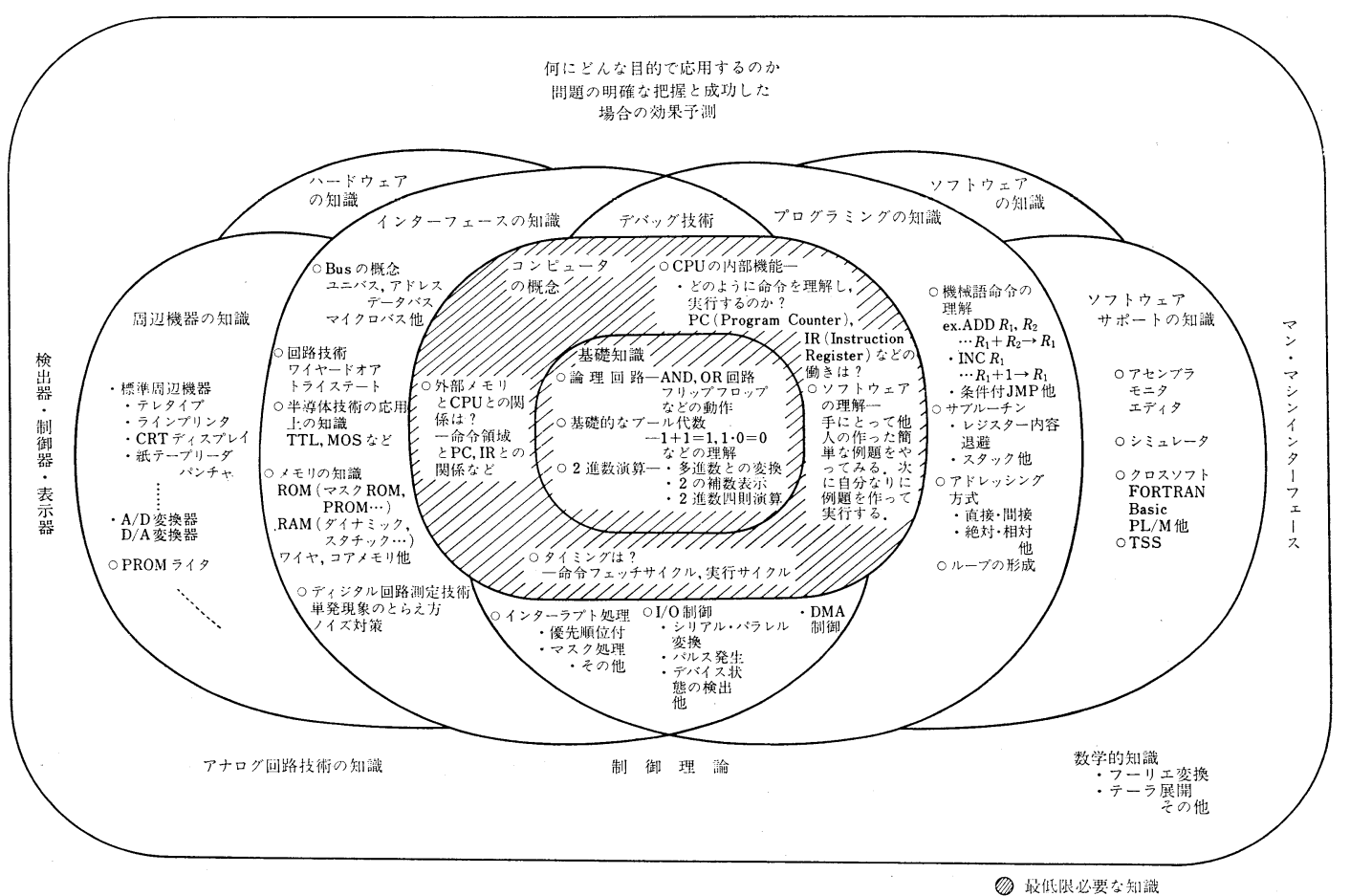

図 13 マイクロコンピュータ応用上必要となる知識

分でないと，システムは完成したが効果は充分でなかっ たといったようなことになる.

本講座では図 13 に示したマイクロコンピュータ活用 のために必要となる基礎について，できるだけ系統的に 説明を加えて行く予定である.

次に, 次回以下の講座であらためて説明するだけの紙
面がないと思われるので，半導体技術からみたマイクロ コンピュータの動向について述べておこう.

\section{6. 半導体技術から見たマイクロコンピュー 夕の動向 ${ }^{9)}$}

マイクロコンピュータに関係の深い半導体技術は, 絶

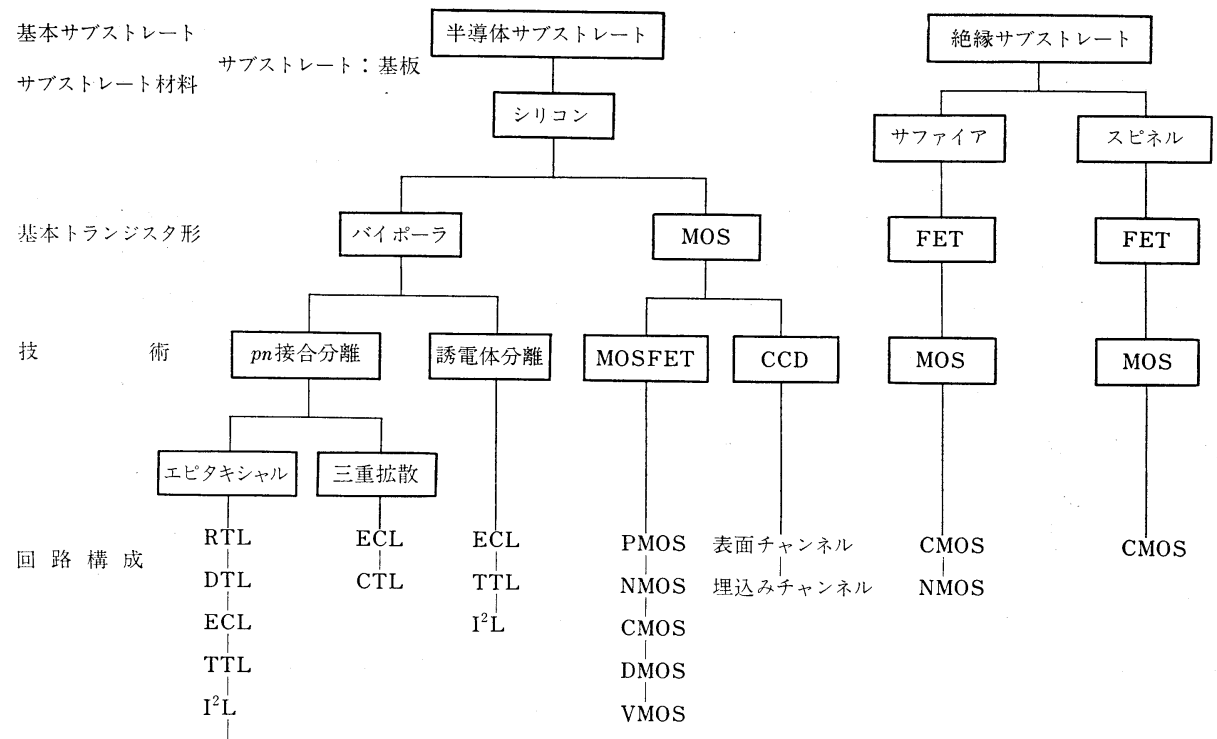

図 14 主な半導体技術 


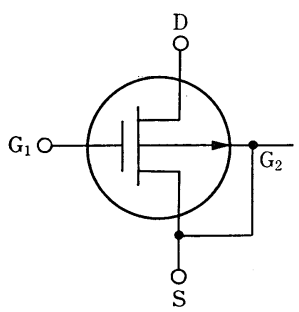

(a) PMOS

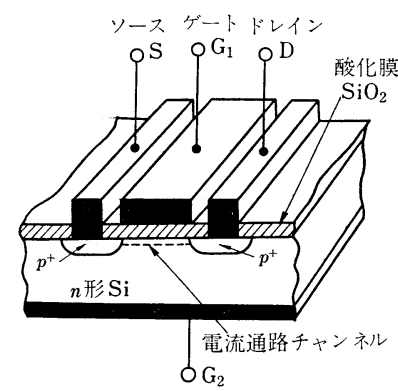

(b) PMOSの構造略図

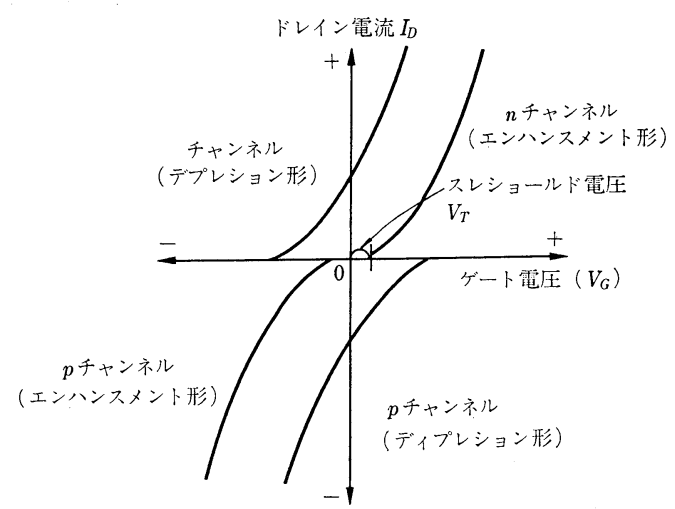

(c) PMOS, NMOS $の V_{G}-I_{D}$ 特性:

図 15 MOS トランジスタの構造と特性

縁ゲート形の電界効果トランジスタに関する MOS 技術 と通常の NPN, PNPトランジスタなどに関するバイポ ーラ技術である. MOS には正孔（ホール）によって動 作する Pチャンネル MOS (以下, PMOS), 電子によ って動作する Nチャンネル MOS (以下， NMOS) と PMOS, NMOS を組合せたコンプレメンタリMOS（以 下 CMOS) があり，バイポーラとしては TTL (transistor transistor logic), ECL (emitter coupled logic), $\mathbf{I}^{2} \mathbf{L}$ (integrated injection logic) などがある. 図14に これらの半導体技術を整理して示した.

\subsection{MOS 技術}

\section{(1) PMOS}

マイクロプロセッサを作るために用いられた最初の技 術で，先に述べた Intel 4004，8008 の他に，Fairchild PPS 25, Rockwell PPS 4, PPS 8, National Semicon IMP などが PMOS で開発された。 図15にMOSトラ ンジスタの構造と特性を示した。

この技術の特長は製造プロセスが比較的単純で，生産 性が高いことや沉用性が高いことである，しかし，閾值 電圧 $V_{T}$ (ドレイン電流を 0 にするためのゲート電圧) が高いとと, スピードが遅いとと, 高い電源電圧が必要 で外部回路としてよく使われる TTL などを駆動する場 合には電圧レベルがそろわないなどの欠点がある。しか

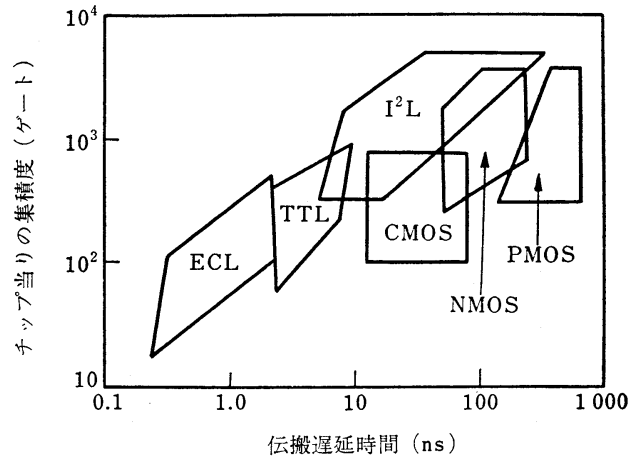

図 16 各技術のスピードと集積度

し，最近ではいろいろ特性改善がはかられており， National Semicon PACE 16 ビット マイクロプロセッサ は PMOS の最む進んだ技術例のひとつである.

(2) NMOS

これは PMOS におけるスピードの欠点を大幅に改善 するむのである．図16にいろいろな技術による伝搬遅 延時間（スイッチング速度）と集積度の関係を示した。

NMOS のマイクロプロセッサを第 2 世代のマイクロ プロセッサと呼ぶことがあり，先に述べた Intel 8080 の 他, Fairchild F-8, Motorola M 6800 などが開発され ている，高集積度が重要視されるもので低・中速応用と して今後の主流技術であろう.

(3) CMOS

図 17 にMOS のインバータ回路を示した. この技 術の特長は

(i) 性能は NMOS と同じか，さらに良い

（ii）きわめて消費電力が少ない

（iii） 単一電源動作ができる

（iv）電源電圧や温度に関する動作範囲が広い

( v ) 雑音に強い

などである. しかし，PMOS や NMOS と比較してコ スト高であり，集積度む低くなりがちである．最近では 新しい製造技術や新しいトランジスタの設計によって,

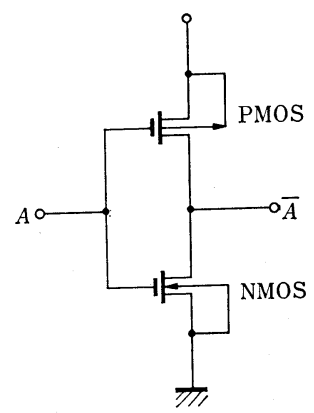

図 17 CMOS インバータ 


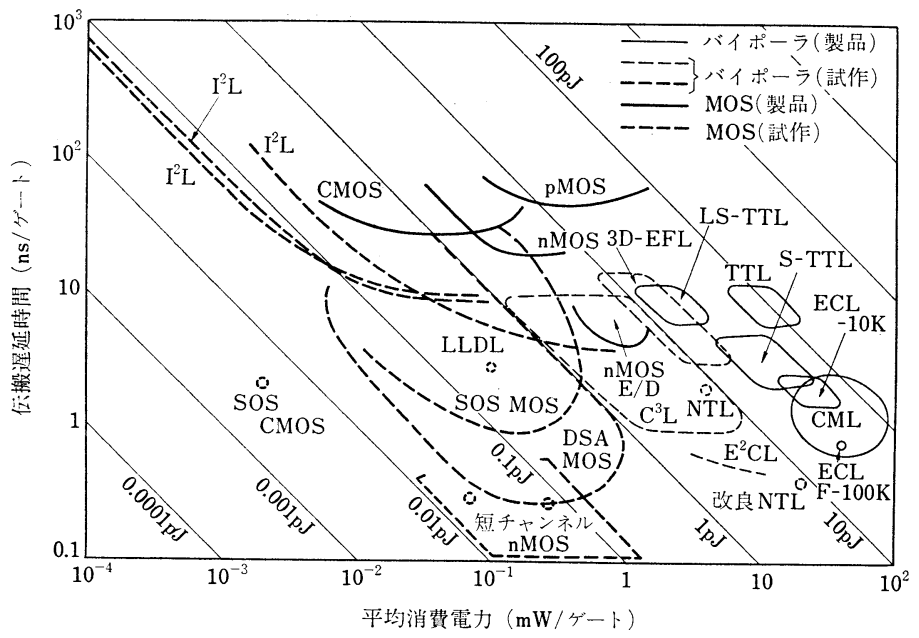

図 18 各技術の消費電力とスピード

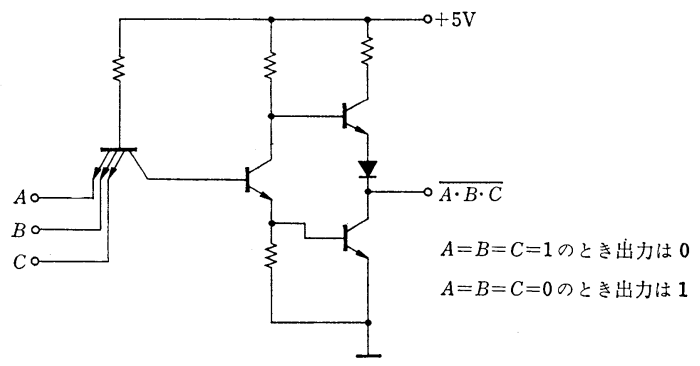

図 19 TTL NAND 回路の例

ゲート当りの面積（トランジスタの集積度を評価する良 い尺度である）む小さくできるようになっている，RCA COSMAC や Intersil IM 6100 などがある.

図 18 にいろいろな技術のゲート当りの消費電力と伝 搬遅延時間を比較した ${ }^{10)}$.

\section{2 バイポーラ技術}

よく知られているように，従来のディジタル IC の大 半がバイポーラロジックであった。一 般的にいって MOS 技術と比較してス ピードは速いが集積度は低い。しか し，最近では I²Lのような技術が開発 されてバイポーラ LSI の可能性がで てきた

(1) TTL

図19に TTL の回路例を示した. マルチエミッタ論理ゲートと出力回路 を組合せてある．TTL はディジタル IC の中では圧到的に多く使われてい るむので，その理由は

（i）いろいろな応用に適した特性 を持っている

(2) ECL

(3) $I^{2} \mathrm{~L}$ （ii） 大変低価格である

（iii） 300 種以上の品種があり選択の 自由度が大きい

（iv）メーカが多く供給が安定してい る

（v）設計者になじみ深い などが考えられる。

一方，LSI 化という見地からはいくつ かの欠点がある.

（i）集積度が低い. 図 20 亿各種ゲ 一トの面積を比較した ${ }^{11)}$.

（ii） 消費電力が大きい.

（iii）製造プロセスが複雑である.

しかし，最近ではいろいろな改良がは かられ，集積度は 1 チップ 300〜400 に なっている，また，消費電力はゲート当 り $10 \mathrm{~mW}$ から $1 \sim 2 \mathrm{~mW}$ になり, スピードむさらに向 上している，マイクロプロセッサ応用としてはユーザが 自分で目的化合った高性能なプロセッサを自由に構成す るために必要となるビットスライス (bit slice) 要素に適 用されている．たとえば，Intel 3001/3002，Fairchild MACRO LOGIC などがある.

消費電力が大きい，集積度が低いなど，LSI 化という 立場からは TTL と同じような欠点を持っている. しか し，各技術の中でスピードは最む速いという特長あが り，大形コンピュータの開発の本命的な技術であると考 えられている. マイクロコンピュータ関連では特殊なむ のへの応用がはかられるとみられる。

図 21 に I'L インバータ回路の一例を示した ${ }^{10)}$. ての 技術はバイポーラマイクロエレクトロニクスのひとつと

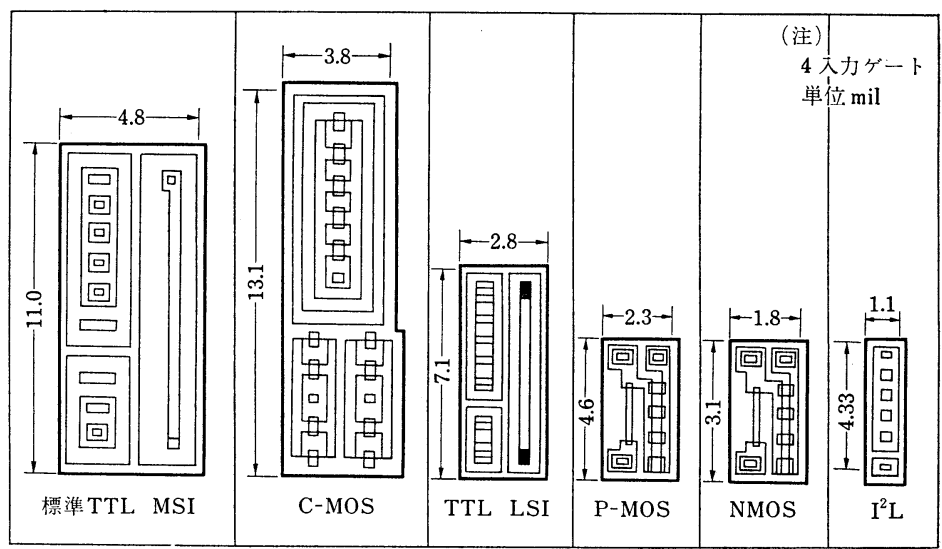

MSI：中規模IC

図 20 素子面積の比較 


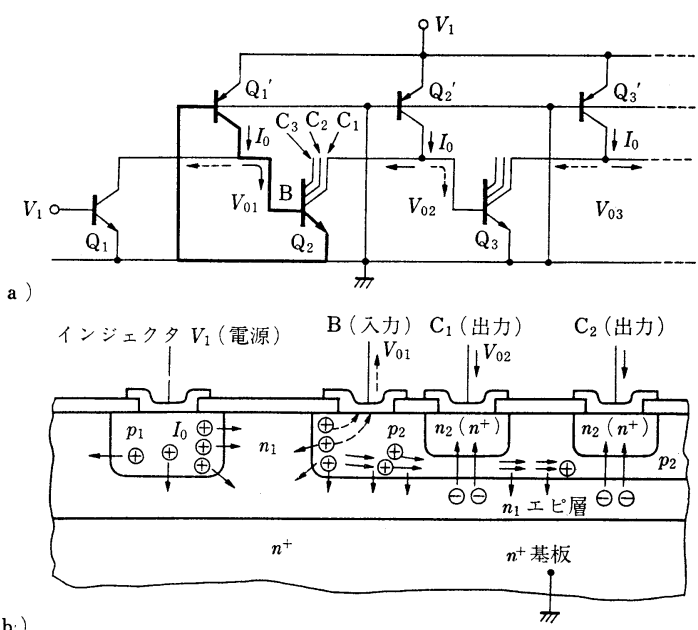

図 $21 \quad I^{2} \mathrm{~L}$ の基本回路と構造

して，その将来に期待がかけられている， I 2 L 技術は集 積度では MOS 技術 ( $1 \mathrm{~mm}^{2}$ 当り 200 ゲート以上) と同 じか，さらに良くなる可能性があり，バイポーラロジッ クのスピードで消費電力は CMOS と競争できるように なると考えられている。

$I^{2} L$ に扔いて高集積度が得られるという理由は，IC 化任当って図 21 亿見ら机るように，比較的大きな面積 を必要とする抵抗を使わないこと，NPN と PNP トラ ンジスタをチップ上でうまく組合せ，ベースとコレクタ が共通となるように配置しているてとなどによる，I²L はこれから数年先 NMOS とマイクロコンピュータのた めの半導体技術のトップの座を争うことになるだろう.

\section{6. むす び}

図 22 にマイクロプロセッサの開発経過をまとめて示 した．乙れからはさらに高性能化され従来のミニコンの 機能をはるかにしのぐようなものす，またさらに高集積 化されワンチップで充分なコンピュータの役目を果すむ の，おどろくほど低価格なマイクロコンピュータの出現 など，ますます幅広い発展が期待できる，

これを推進するむのはマイクロエレクトロニクス技術 と応用技術の両方の技術の進展にかかっている.すずに 冒頭であ述べたように，放送にとって技術は手段であり 活用しててそ価值がある，皆さんには本講座によってマ イクロコンピュータやマイクロエレクトロニクスの本質 をマスタされ，乙れらを活用するてとによって明日の放 送を切り開いていただきたい。なお講座に関してご希望 があれば学会事務局あてにで連絡いただければ幸いで す。

最後に図 13 や図 22 の作成その他でで協力いただいた NHK 総合技研番組技術班 村上，榎並研究員に感謝の意 を表する。

\section{〔参 考 文 献〕}

1) G.E. Moore: Microprocessers and Integrated Electronic Technology, Proc. IEEE, 64,6 (1976) 837

2）後藤：自作マイクロコンピュータと TV ゲーム, テレ ビ技術，1 3(1977）47，59，31

3）和久井, 大関：マイクロコンピューターを用いたダイレ クトディジタルコントロール，テレビ誌，30,10(1976) コ 877

4）楢原，八尾：マイクロコンピュータを使用した音声特性

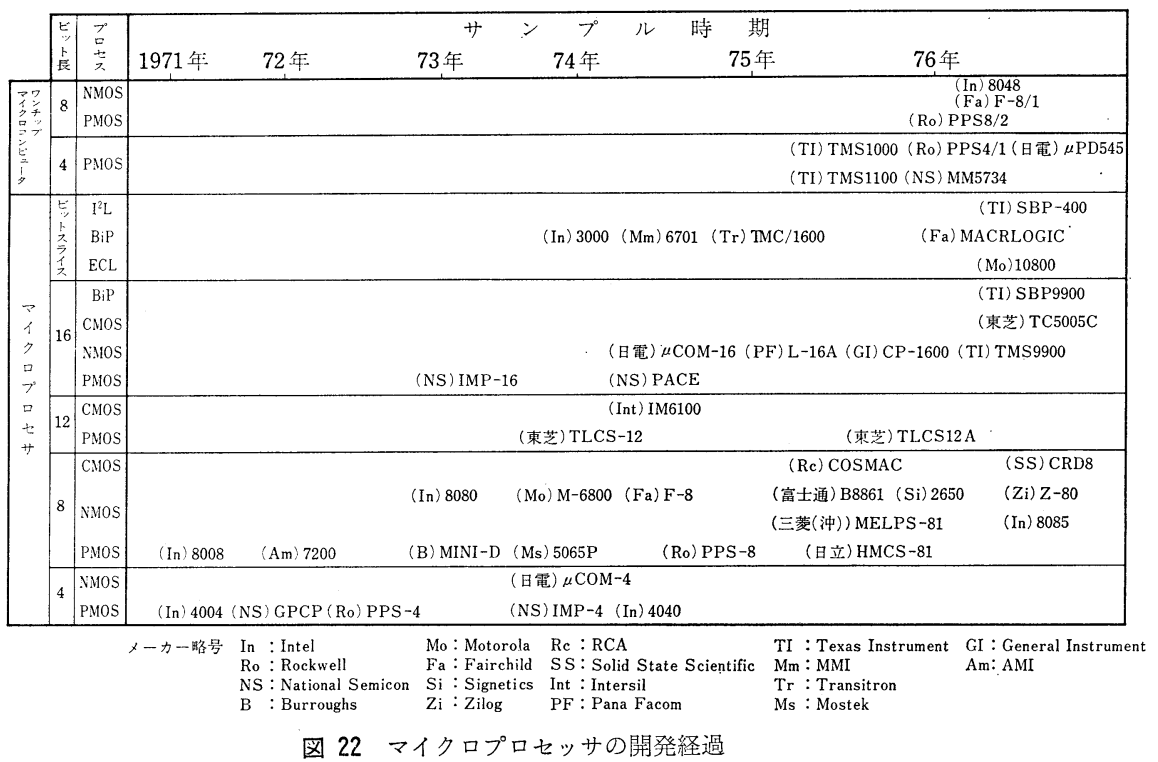


自動監視装置，テレビ学会無線技術研資 (1974)

5）坂井, 坂本, 若松ほか：マイクロコンピュータを用いた FPU パラボラの自動方向調整システム，テレビ学会方 式回路研資, TBS 30-1 (1976. 7)

6) 服部, 臼井, 大矢ほか: テレビジョン画像の連続縮小効 果，テレビ学会方式回路研資, TBS 33-2 (1976.11)

7) 伊藤：時間軸処理,テレビ誌，30，10 (1976)

8) 石川ほか：MOS RAM を応用した特殊効果発生器, テ レビ学会方式回路研資，10-3 (1974)
9) P. W. J. Verhofstadt: Evaluation of Technology Options for LSI Processing Elements, Proc. IEEE, 64, 6 (1976) 842

10) 岡部：MOS に挑戦する $I^{2} L$ の可能性を探る，日経エレ クトロニクス (1976. 5.17) 58

11) R. L. Horton, et al.: $I^{2} \mathrm{~L}$ takes bipolar integration a significant step forward, Electronics (1975.2.6) 83

講座 テレビ・ラジオ技術者のためのマイクロコンピュータ

\section{用 語 集 (1)}

〔注〕この用語集は講座の進行に応じて順次補足する予定になっています，用語集の中で新しい専 門用語がでてくる場合がありますが，次回以下であらためて説明があります。

〔あ 行〕

アイ・アイ・エルまたはアイスクエア・エル $I^{2} \mathrm{~L}$ (integrated injection logic)

ラテラルPNP トランジスタを電流バイアス素子として用い, マルチコレクタNPNトランジスタをスイッチング素子として用 いた回路構成で, LSI 化に適した新しいバイポーラ論理回路. … -.本文参照

アクセス, アクセスタイム access, access time アクセス (呼び出し) は一般にメモリを呼び出すととを意味す る.アクセスタイムはメモリ (装置) が動作命令を受けてから情 報読取り可能または書込みが完了するまでの時間.

アナログ(信号) analog (signal)

各種の物理的変量に相似な電気量, 電気信号またはその他の エネルギー形態の信号. 值が時間的に連続である電圧, 電流で 広義にはディジタル信号以外の信号.

ECL emitter coupled logic circuit

エミッタ結合論理回路とも呼ぶ. エミッタで結合されたトラ ンジスタ間の電流切換えによって論理演算を行う現在実用化さ れている最む高速な論理回路. ……本文参照

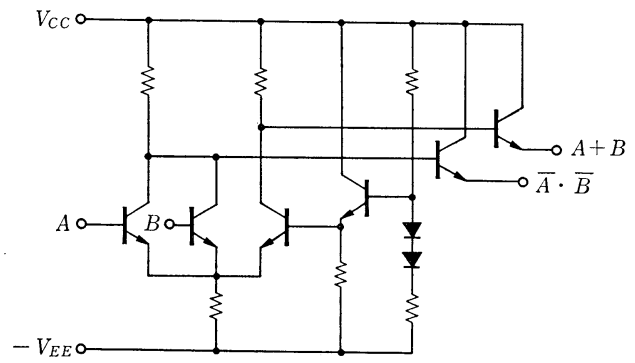

インターフェース interface

信号のやりとりを行うように接続されている2つの装置ある いはシステムの境界部分. たとえばマイクロコンピュータと外 部装置の境界. この他インターフェース回路や装置などを略し てインターフェースと呼ぶ場合がある.

$$
\begin{aligned}
& \text { インターラプト } \Longrightarrow \text { 割込み } \\
& \text { インバータ inverter }
\end{aligned}
$$

極性反転回路のことで, 論理回路では否定回路（NOT 回路） に相当する. 0 のとき出力が 1 になる回路.

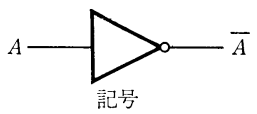

A/D 変換器 analog to digital converter アナログ信号を規定のビット長のディジタル信号に変える変 換器. 逆にディジタル信号をアナログ信号に変える装置を D/A 変換器と呼ぶ. アナログデータをマイクロコンピュータに読取 らせる場合はに A/D 変換器が必要で, マイクロコンピュータシ ステムからアナログ信号の形で出力を得ようとする場合は D/A 変換器が必要となる.

LED (ディスプレイ) light emitting diode (display)

発光ダイオード表示器のととで, $\mathrm{GaP}$ (赤, 緑), GaAsP(赤) などいろいろな構造のものが生産されており，LED チップをド ットマトリックス状に配置したり, 放射セグメント形式で数字 や文字を表示（ディスプレイ）するデバイス.

キャラクタディスプレイデバイスが開発されている．とのよ うなデバイスを用いてマイクロコンピュータの出力を表示する

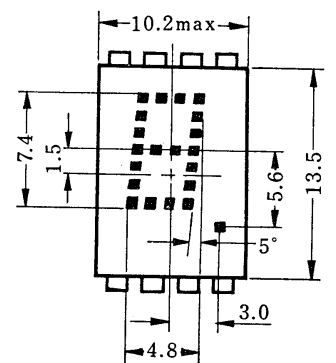

ドットマトリックス表示の例

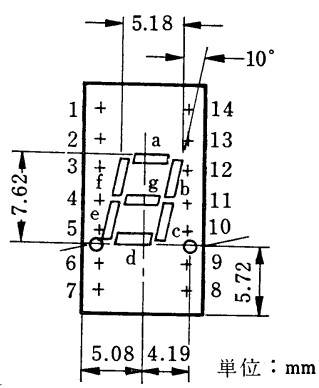

放射セグメント表示の例 
ととができる.

LSI large scale integrated circuit

大規模集積回路のことで，1つのパッケージに 1000 素子(100 ゲート) 以上程度集積化したものを指す. これに対して 100〜 1000 素子集積を MSI, 100 素子以下を SSI と呼ぶ. しかし, 広 義には MSI をむ含めて LSI と呼ぶ場合あある.

NMOS N channel metal-oxide semiconductor

酸化膜によって電流通路から絶縁されたゲート電極に電圧を 印加し，ソース電極とドレイン電極間の電流通路を制御するこ とによって動作するトランジスタを MOS トランジスタと呼び, P形基板を用い電流通路を流れるキャリアが電子であるあのを NMOS と呼ぶ. これに対してN形基板を用いキャリアが正孔で あるあのを PMOS と呼ぶが, NMOS は PMOS より動作速度 が速い. ……本文参照

\section{〔か 行}

画像処理 image processing

画像情報を加工するとと.カラーカメラで行われている輪郭 強調などは，アナログ的な画像処理の一例であるが，最近では ディジタル技術を応用した画像処理む多く行われるようになっ てきている，電子ズーミングなどはその一例である.

キイボード key-board

情報を入力するための鍵盤のとと. マイクロコンピュータの 入力装置としても用いられ，鍵盤を用いて数字，文字，特殊記 号などを入力する.

機能デバイス functional device

所要の信号または (および) エネルギー処理, 変換などの特有 な機能を持たせたデバイス．この講座では主として特定の信号 処理機能を持った ICのとと.

キャラクタディスプレイ character desplay

アルファベットやカタカナなどの文字, 記号や数字を表示す る装置で, CRT を使ったものや LED 式, 放電管式, 機械式な どいろいろな方式があるが，簡便なあのとしては LED 式が 最近では多く用いられる. アルファニニーメリック表示器 (alphanumeric display) などとも呼ばれる.

グラフィックディスプレイ graphic desplay

図形表示装置 (器)のととで図形以外にむ文字, 数字, 記号な どが表示できる. CRT ディスプレイを使ったあのが多い.

クロック clock

回路および装置相互間の動作に時間的な基準を与え，同期を とるために周期的に発生する信号またはその信号源.

ゲート(回路) gate (circuit)

複数個の入力端子を持ち, これらの入力に加わった信号の論 理演算を行う. たとえば AND ゲート，OR ゲートなどいくつ かの種類がある.

\section{〔さ 行〕}

シーケンス制御 sequential control

あらかじめ定められた順序に従って制御の各ステップを順次 進めていく制御法. ……本文参照

CPU central processing unit

中央処理装置とむいう. コンピュータの論理的中枢であり, 命令を解読して実行する装置. コンピュータの他の装置の動作 を統合，制御し，算術および論理演算を実行する.
CMOS complementary metal oxide semiconductor 相補形MOS とむいう．Pチャネル形とNチャネル形の MOS トランジスタを同一チップ上に作り論理回路を構成するすの で，消費電力が小さい，雑音に強いなどの特長がある。......本文 参照

ソフトウェア software

あるシステムに括いて所要の効果を得るのに必要な考え方(思 想）を広義のソフトウェアと呼ぶ. そして，てのような考え方を コンピュータが実行可能な命令群で表現したものをプログラム と呼ぶが，狭義にはプログラムのととをソフトウェアと呼ぶ.

すなわち，モニタなどのコントロールプログラム，ローダなど のユーティリティプログラム, アセンブラなどの翻訳プログラ ムをシステムプログラムと呼ぶが，てれとデバッグ用のプログ ラム (デバッガ) などを合せてサポートウェアという．ソフトウ ェアとはとのようなサポートウェアとユーザが自分の問題処理 のために作ったユーザプログラムを含めたあのである.

\section{〔た 行〕}

ダイレクトディジタル制御 direct digital control $\Longrightarrow \mathrm{DDC}$

ディジタルコンピュータを用い時分割方式により, 制御対象 を直接制御する制御方式で，ループ内にコンピュータ処理を含 む自動制御方式. ……本文参照

チップ chip

半導体技術用語で受動素子, 能動素子または集積回路を作り 付けた，屯しくは作り付けることを前提とした半導体または絶 縁物の細片. 1 個のパッケージに収められた集積回路を指すと とがある. 1 個のチップに集積された CPU はワンチップ CPU と呼ばれる。

\section{チャンネル（チャネル） channel}

コンピュータ関係では情報の流れる通路のとと, また, 半導 体関係では電流の流れる通路のととをいう。

\section{中央処理装置 $\Longrightarrow \mathrm{CPU}$}

DMA direct memory access

CPU の管理を受けずに直接データを入出力装置あるいは外部 メモリとメインメモリの間で転送する手法. メモリからの画像 の読み出しなど TV 走査レートで処理をするような場合にあ用 いられ，乙のような手法によってマイクロコンピュータに高速 な入出力機器を接続するととができる．……本文参照

\section{データロギング data logging}

logging の屯との意味は航海日誌をつけるとと. マイクロコ ンピュータを用い観測対象から必要なデータを自動的に測定 し, 処理を行って所定の形式に整理してデータの報告を行うこ 之. ……本文参照

TTL (回路) transistor transistor logic (circuit)

最屯一般的な IC 論理回路. マルチエミッタトランジスタ論理 ゲートとトランジスタ出力回路の組合せで構成される. 飽和形

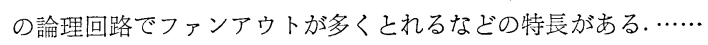
本文参照

\section{ディジタル digital}

基本量の倍数として数值化した表現をディジタル的な表現 （離散的な表現，てれに対してアナログは連続的な表現）とい う.とれらの数字または記号によって計数できる情報は, すべ ての情報の最小単位である「なし」,「あり」「「0」，「1」に分解 
するととができ，情報量は 2 を底とする対数で表わされる．た とえば $M$ 個の情報があったときの情報量 $N$ は,

$$
N=\log _{2} M
$$

である.すなわち，「0」，「1」を表現できるデバイス $N$ 個を用 いれば $2^{N}=M$ 個の数を表わすととができる．また，てのよう な情報の最小単位〔「0」,「1」〕を 1 bit（ビット）と呼ぶ.

ディジタル回路 digital circuit

区別可能な複数個の物理状態をとる素子または素回路を用い， その物理状態で情報を取扱う回路. 電流, 電位の「低」, 「高」 「「0」,「1」やスイッチの開，閉などの物理状態を利用する屯 のが多い.

ディジタル回路によって各種のゲート, フリップフロップ, レ ジスタ, 加算器, 累算器などのような論理ブロックを構成する てとができる. マイクロエレクトロニクスの発達によって, こ れらの諭理ブロックの寸法が非常に小さくなり, 性能, 信頼性 が向上し，低洒格化した．乙のようなマイクロエレクトロニッ ク化されたディジタル技術がマイクロコンピュータと関連技術 を生み出した。

ディスプレイ display

表示するとと. 表示器……ャラクタディスプレイ, グラフィ ックディスプレイの項参照.

テレタイプ tele-type-writter (TTY)

国際情報交換 (テレックス) 用の端末装置で, 米国テレタイプ 社の商品名である. 比較的安価なため, ミニコンピュータなど の入出力装置としても広く用いられている. 入出力は単純化さ れており,データは ASCII (american standard code for information interchange) コードによっているものが多い.

伝搬遅延時間 propagation delay time

ディジタル信号がディジタル回路の中を伝送される時に生ず る遅延時間. 立上り遅延時間 $t_{r d}$ 之立下り遅延時間 $t_{f d}$ の平均 值で表わす. 伝搬遅延時間 $t_{p d}$ は次式で与えられる.

$$
t_{p d}=\frac{t_{r d}+t_{f d}}{2}
$$

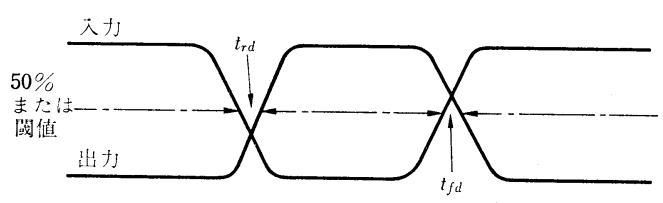

〔な 行〕

内挿 inter polation

サンプリングシステムに扔いて，サンプル值間の失われてい る情報を, 相関性のあるサンプル值の合成によって補間する手 法で, テレビジョン信号を画像処理する電子ズーミングや方式 変換などにおいては，幾何ひずみや動きの不自然さを改善する ため, 信号の時間的相関 (フレーム間相関) と空間的相関（フレ 一ム内相関）を利用した内挿が考えられている.

フレーム間相関を利用したすのは画像の静止部分の補間に有 効で, フィールド数変換を伴う方式変換において, フィールド 内挿と呼ばれている，フレーム内相関を利用した内插は画像の 動いている部分に有効で, 垂直方向の相関を利用したライン内 插，水平方向の相関を利用した，電子ズームに扔けるドット内 挿などがある.

\section{入出力装置 $I / O$ 装置}

コンピュータに情報を入れるための入力装置, コンピュータ から外部に情報を出すための出力装置を合せて入出力装置と呼 ぶ. テレタイプなどは代表的な入出力装置であり，キイボード， テープリーダ, カードリーダは入力装置, 各種のディスプレイ は出力装置である.

\section{〔は行〕}

ハードウェア hardware

ハードウェアとは本来, 金物のことで，コンピュータを構成し ている CPU やメモリ，入出力装置それらを取付けている筐体 とか配線といったあのをさす．とれに対してコンピュータを動 作させるためのプログラムをソフトウェアと呼ぶ.

ハードウェア技術といった場合には半導体技術や回路技術, 周辺機器関連技術などを指す.

バイポーラトランジスタ bipolar transistor

その動作に 2 種類のキャリアすなわち電子と正孔の共存を必 要とするトランジスタ. PNP, NPN トランジスタなど. これに 対して 1 種類のキャリアだけで動作する MOS トランジスタの ようなあのはユニポーラトランジスタと呼ばれる.

バイト byte

8 ビットからなるビット群をさす. 1 バイトで 1 英文字, 半バ イトで1数字が表示できる.

ハイブリッド IC (LSI) hybrid integrated circuit

混成集積回路とも呼ばれる，2つ以上の巽なった種類の集積 回路や 1 つ以上の独立したデバイスを組合せて 1 つのパッケー ジ内に集積したもの. 薄膜や厚膜の受動集積回路内にトランジ スタ, ダイオード, モノリシック ICなどの能動素子を組込んだ あのが多い.

半導体メモリ semiconductor memory

ICメモリとも呼ばれる．「０」，「1」（2進コード）のデータ や命令を記憶する半導体デバイスで, 次に示すようないろいろ な種類のものが利用される.

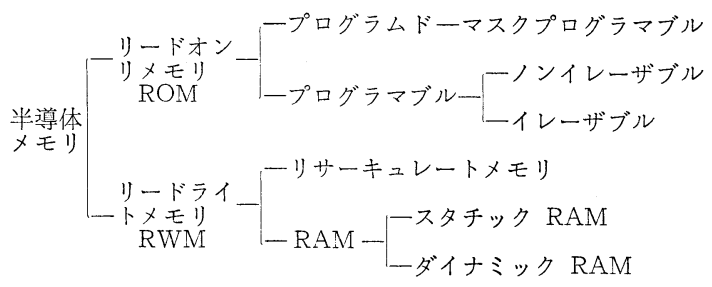

BCD コード binary-coded decimal notation code 2 進化 10 進数. 数の表記方式の一種で, 10 進法に拈ける各 10 進数字を 2 進法によって表わす方式. 自然 2 進の 4 杕は 10 進 数の 16 までを表示できるが, BCD コードでは最初の 4 桁で 9 までを表示し，10 以上は上位の 2 進 4 桁で表示する. との方式 は 10 進法との対応が容易なので出力表示などに用いられる.

PLL phase-locked loop

位相同期ループとあ呼ばれる. 基本的には入力信号に位相同 期した発振出力を得ることを目的とした回路であるが，最近 IC 化された高性能で低洒格なPLL が生産されるようになり, AM, $\mathrm{FM}$ 波の検波, 色同期回路, ディジタルチューナ, 周波数シン セサイザなど多方面に利用されるようになっている，基本的な PLL のブロックダイヤグラムを示した. 


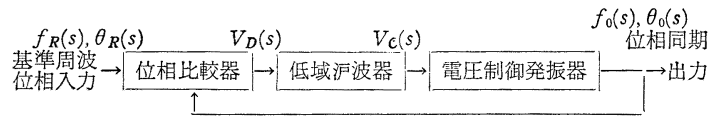

PMOS P channel metal oxide semiconductor

N形基板を用い電流通路を流れるキャリアが正孔であるよう な MOS トランジスタ. 他のデバイスにくらべて製造方法が最 屯簡単であり製品の歩止りが高いという特長がある.......NMOS の項拉よび本文参照

\section{ビット bit}

binary digit を略して作られた語で， 2 進数字と同じ意味を 持つ. また, 情報量の単位としても用いられ，1個の 2 進数字 の保有し得る最大情報量を表わす。.......゙ィィジタルの項参照

\section{ビットスライス bit slice}

コンピュータのハードウェアを, ビット方向に何ビットかず

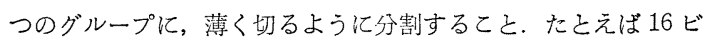
ットの並列機能をビット方向で 4 分割すると 4 ビットスライス 機能となる. このような方法によってコンピュータ構成法に柔 軟性を生じ，高速 IC などす使用できる.

フィードフォワード制御 feed-forward control

制御系に外乱が入った場合, それが系の出力に影響をおよぼ す前に先まわりして，その影響を打消すような訂正動作をする 制御方式. コンピュータによる最適化制御ではこのような方式 がとられるととが多い. 入力 (外乱) と出力の関係は数学モデル の形で表現し, 状態の推移に合せてモデルに修正を加える.

プログラム（プログラム内蔵コンピュータ） program (stored program computer)

プログラムとはコンピュータを動作させるためのソフトウェ アである.……フトウェアの項参照

コンピュータの動作を規定するプログムそのあのあデータと 同様に内部メモリの中に記憶し必要な処理をを実行するコンピ ユータをプログラム内蔵コンピュータと呼び, マイクロコンピ ュータを含む一般的なコンピュータはすべてての方式である. このようなシステムでは場合によってはプログラムの内容を白 分自身で変更しながら処理を実施するとともある.

プログラマブルオシレータ programable oscillator ディジタル制御発振回路とす呼ばれる. 発振周波数拈よび必 要に応じては出力レベルをディジタル入力によって制御できる 発振回路で, PLL 周波数シンセサイザなどもこの分類に入る. 連続周波発振器ではディジタル入力を D/A 変換器で DC にし てから電圧制御発振器を制御するような方法むとられる.レベ ル調整はディジタルアッテネータなどが用いられる.

\section{〔ま行〕}

マイクロエレクトロニクス microelectronics

超小形電子技術のことで半導体の超精密, 微細加工技術を主 軸とした電子技術の総称である. ……本文参照.

マイクロコンピュータ microcomputer

マイクロコンピュータはデータを処理する中央処理部 (CPU) とデータを蓄積するメモリ部より構成されるため, 処理手順自 身を 1 つのデータとみなして, メモリに蓄積するととができる 点が, 他のテレビゲーム用の LSI と本質的に異なり, 大形コ ンピュータ〜ミニコンなど, コンピュータ一般に共通した， ス トアドプログラム方式を特長とするコンピュータに位置づけら れている.したがって，プログラムしだいでテレビゲームや䓢
組自動送出など，全く別の仕事を処理することも可能である.

現在のマイクロコンピュータはCPUが1チップ, メモリ部を 数チップ組合せて構成したものが多いが,メモリ部を CPUに内 蔵した 1 チップマイクロコンピュータも発売されはじめてい る. ……本文参照

マイクロプロセッサ microprocessor

マイクロコンピュータのCPU 部分に相当するもので通常メ モリは含まれない.コンピュータの論理的処理機能部分を 1 個 ないし数個の LSI に集積したむの. ……本文参照

メモリ(装置) memory (device)

メモリと記憶とは同義語であるが，記憶装置のととをメモリ と呼んでいる場合も多い. 記憶とは処理に必要な情報を所要の 時間たくわえておくこと. 記憶装置は情報の書込み, 読出し, 消 去の全部あるいはその一部のみができるあのがある.コンピュ 一タ用の記憶装置には次のようなものがある.

ランダムアクセスメモリ——半導体メモリ(別項の説明参照), コアメモリ, ワイアメモリ

連続メモリ一磁気テープ, カセット式磁気テープ

循環メモリ一磁気ディスク, 磁気ドラム, フロッピーディスク

MOS トランジスタ metal-oxide semiconductor transistor

酸化膜により電気的に電流通路から絶縁されたゲート電極に 電圧をかけて電流通路を制御する電界効果トランジスタ.…... PMOS, NMOS, CMOS の項参照

モノリシック IC (LSI) monolithic integrated circuit

1 個の半導体チップ内に作られた集積回路. 一般に IC といっ た場合はモノリシック IC を指すととが多い.

\section{[5 行 $]$}

論理 (論理学, 論理数学) logic

論理学ははじめ人間の考え方のすじみちを研究する学問とし てはじまったため「正しい」か，「正しくない」かといった 2 值的 な考え方を基本として組立てられた。 てれを 2 值論理学といい, 論理学の基本となっている.

一方, 命題之命題の関係を数学的に論じるものとして, 数学的 論理学 (記号論理学, 論理代数などとあ呼ばれる) があるいま, 命題が「正しい」ととを電子回路の「1」の状態に, また命題が 「正しくない」ととを「0」の状態に対応させると, 数学的論理 学を用いてスイッチ回路やディジタル演算回路の動作条件を求 めることができる.すなわち，てのような意味合いから回路の 「0」,「1」によって情報を処理するコンピュータの中枢部は, 論理用処理機能の中心であるといえる.

論理演算 logical operation

幾つかの論理変数の論理値の組合せに対して新しく論理値が 定まる演算のとと. 代表的なものとして論理和, 論理積, 否定な どがある。

\section{〔わ 行〕}

割込み interruption

プログラムの分岐の一種であるが，分岐命令によるむのでは なく、ハードウェア的な信号によって行われる分岐.

ワンチップマイクロコンピュータ

マイクロコンピュータの項参照.

\section{ワンチップ CPU}

CPU の項参照. 